Volume 1 Issue 1, January 2022: pp. 1-30. Copyright @ NoLaJ.

Master of Notary, Faculty of Law, Lambung Mangkurat University,

Banjarmasin, South Kalimantan, Indonesia. ISSN: 2808-7860 | e-ISSN: 2808-7348

Open Access at: https://notarylaw.journal.ulm.ac.id/index.php/nolaj

\title{
Sistem Pendaftaran Tanah yang memberikan Perlindungan Hukum Bagi Pemegang Sertifikat Hak atas Tanah di Indonesia
}

\author{
Arie Lestario $^{1}$, Erlina ${ }^{2}$ \\ Magister Kenotariatan Fakultas Hukum Universitas Lambung Mangkurat \\ Jl.Brigjen H.Hasan Basry, Banjarmasin, Indonesia, 70123 \\ Email: advokatarie@gmail.com \\ Fakultas Hukum Universitas Lambung Mangkurat \\ Jl.Brigjen H.Hasan Basry, Banjarmasin, Indonesia, 70123 \\ Email:erlina@ulm.ac.id
}

Submitted : 05-10-2021 Reviewed:25-10-2021 Accepted:02-11-2021

\begin{abstract}
The objectives of this research are to study the land registration system which can provide legal protection and legal certainty to the holder of land right and to study right land registration system to enforce in indonesia. This is normative legal research, using statute approach, conceptual approach, and comparative approach. The result of the research show the negative publicity system has positive tendency which is applied in land registration system in indonesia as the cause of inconsistency of legal protection and legal certainty to the holder of land right certificate of right as strong instrument of evidence, where the State does not guarantee the truth of physical data and legal data recorded in the said document of evidence. The role of the State as stipulated in Article 33 Paragraph (3) of 1945 Constitution cannot be applied to provide legal protection and legal certainty to the holder of land right certificate is the one which has positive publication system. Positive publication system is most ideal applied in land registration system in Indonesia which provides legal protection and legal certainty to the holder of land right certificate because the proof of right document is strong instrument of evidence and the State guarentees the truth of physical data and legal data recorded in the said document of evidence
\end{abstract}

Keywords: Holder of Land Right Certificate; Land Registration System; Legal Protection

Abstrak: Penelitian ini bertujuan untuk mempelajari sistem pendaftaran tanah yang dapat memberikan perlindungan hukum dan kepastian hukum kepada pemegang hak atas tanah dan mempelajari sistem pendaftaran tanah yang berlaku di Indonesia. Penelitian ini merupakan penelitian hukum normatif, dengan menggunakan pendekatan undang-undang, pendekatan konseptual, dan pendekatan komparatif. Hasil penelitian menunjukkan sistem publisitas negatif memiliki kecenderungan positifyang diterapkan dalam sistem pendaftaran tanah di Indonesia sebagai penyebab tidak konsistennya perlindungan hukum dan kepastian hukum kepada pe- 
megang sertifikat hak atas tanah sebagai alat bukti yang kuat, dimana Negara tidak menjamin kebenaran data fisik dan data hukum yang tercatat dalam dokumen bukti tersebut. Peran negara sebagaimana diatur dalam Pasal 33 Ayat (3) UUD 1945 tidak dapat diterapkan untuk memberikan perlindungan hukum dan kepastian hukum kepada pemegang sertifikat hak atas tanah adalah yang memilikipositif sistem publikasi. Sistem publikasi positif paling ideal diterapkan dalam sistem pendaftaran tanah di Indonesia yang memberikan perlindungan hukum dan kepastian hukum kepada pemegang sertifikat hak atas tanah karena surat bukti hak merupakan alat bukti yang kuat dan Negara menjamin kebenaran data fisik dan data hukum. dicatat dalam dokumen bukti tersebut;

Kata Kunci: Pemegang Sertifikat Hak Atas Tanah; Hukum Perlindungan

\section{PENDAHULUAN}

Negara mempunyai wewenang menurut konstitusi untuk menguasai tanah yang berada dalam wilayah Negara Kesatuan Republik Indonesia, mengatur rakyat dalam mendapatkan hak menguasai tanah berdasarkan Pasal 4 Undang-Undang Nomor 5 Tahun 1960 tentang Peraturan Dasar Pokok-pokok Agraria. Hak-hak yang diberikan oleh negara kepada rakyat untuk memiliki dan mengelola tanah yang disebut sebagai hak primer. Hak-hak atas tanah yang bersifat primer adalah hak-hak atas tanah yang diberikan oleh Negara atas dasar hak menguasai Negara yang bersumber langsung dari hak bangsa Indonesia atas tanah. Hak-hak atas tanah primer adalah hak milik, hak guna usaha, hak guna bangunan yang diberikan oleh negara, dan hak pakai yang diberikan oleh negara. Tanah-tanah yang dikuasai secara individual dengan hak-hak atas tanah yang primer tersebut disebut tanah-tanah hak. ${ }^{1}$

Undang-Undang Pokok Agraria mengintruksikan pemerintah untuk melakukan pendaftaran tanah, maka sudah sangat jelas pemerintah dalam hal ini wajib menjamin kepastian hukum dan perlindungan hukum. Pasal 19 ayat (1) Undang-Undang Pokok Agraria berbunyi untuk menjamin kepastian hukum oleh pemerintah diadakan pendaftaran tanah diseluruh wilayah Republik Indonesia menurut ketentuan-ketentuan yang diatur dengan peraturan pemerintah. Kemudian ayat (2) huruf c, dalam rangka mewujudkan implementasi kepastian hukum bahwa "Pemberian surat-surat tanda bukti hak, yang berlaku alat pembuktian yang kuat". Oleh pemerintah dikeluarkan peraturan pelaksana untuk mewujudkan hal tersebut yaitu dengan dikeluarkan Peraturan Pemerintah Nomor 10 Tahun 1961 tentang Pendaftaran Tanah sekarang telah diubah dengan Peraturan Pemerintah Nomor 24 Tahun 1997 tentang Pendaftaran Tanah. Pasal 1 angka 1 Peraturan Pemerintah Nomor 24 Tahun 1997,yang dimaksud Pendaftaran Tanah adalah serangkaian kegiatan yang dilakukan oleh Pemerintah secara terus menerus, berkesinambungan dan teratur, meliputi pengumpulan, pengolahan, pembukuan dan penyajian serta pemeliharaan data fisik dan data yuridis dalam bentuk peta dan daftar, mengenai bidang bidang tanah dan satuan rumah susun, termasuk pemberian surat tanda bukti hak nya bagi bidang bidang tanah yang sudah ada hak nya dan hak milik atas satuan rumah susun serta hak hak tertentu yang dibebaninya

Sistem pendaftaran tanah yang dianut oleh Indonesia, adalah sistem publikasi negatif yang bertendensi positif, dalam sistem ini menggunakan sistem pendaftaran hak, artinya

\footnotetext{
${ }^{1}$ Urip Santoso, Hukum Agraria Dan Hak-Hak Atas Tanah (Jakarta: Kencana, 2005).
} 
data fisik dan data yuridis atas tanah tersebut dianggap benar sepanjang tidak ada yang menyanggah kebenaran data tersebut.

Bahwa tujuan dibentuknya peraturan pemerintah tentang pendaftaran tanah adalah untuk memberikan kepastian hukum dan perlindungan hukum bagi pemegang sertifikat hak atas tanah, Peraturan Pemerintah Nomor 24 Tahun 1997 ada lembaga baru yaitu lembaga rechtsverweking yaitu lembaga dalam hukum adat yang namanya kehilangan hak menuntut atau rechtsverweking yang intinya apabila seorang yang mempunyai tanah, tetapi selama jangka waktu tertentu membiarkan tanahnya tidak terurus, dan tanah tersebut digunakan oleh orang lain dengan itikad baik, pemilik tanah tersebut tidak dapat lagi menuntut pengembalian tanah tersebut kepada orang yang menguasai nya ${ }^{2}$. Prinsip lembaga rechtsverweking ini dituangkan dalam Pasal 32 ayat (2) Peraturan Pemerintah Nomor 24 Tahun 1997 yang berbunyi dalam hal atas suatu bidang tanah sudah diterbitkan sertifikat secara sah atas nama orang atau badan hukum yang memperoleh tanah tersebut dengan itikad baik dan secara nyata menguasainya, maka pihak lain yang merasa mempunyai hak atas tanah tersebut tidak dapat lagi menuntut pelaksanaan hak tersebut apabila dalam kurun waktu 5 tahun sejak diterbitkannya sertipikat itu, tidak mengajukan keberatan secara tertulis kepada pemegang sertipikat dan Kepala Kantor Pertanahan yang bersangkutan ataupun tidak mengajukan gugatan ke Pengadilan mengenai penguasaan tanah atau penerbitan sertifikat tersebut. Tetapi lembaga ini tidak efektif karena dalam Pasal 19 ayat (2) huruf c yang berbunyi pemberian surat surat tanda bukti hak, yang berlaku sebagai alat pembuktian yang kuat. Kalimat sebagai alat pembuktian yang kuat, disini menegaskan bahwa sistem pendaftaran tanah menganut sistem publisitas negatif, yang mana subjek hak yang namanya sudah terdaftar, masih dimungkinkan diajukan keberatan-keberatan oleh pihak-pihak yang merasa haknya diambil.Jadi lembaga rechtsverweking ini tidak dapat dilaksanakan karena bertentangan dengan Pasal 19 ayat (2) huruf c Undang- Undang Pokok Agraria.

Salah satu akar permasalahan konflik agraria disebabkan oleh sistem pendaftaran tanah yang digunakan di Indonesia berupa sistem publisitas negatif bertendensi positif. Dalam sistem pendaftaran negatif (stelsel negatif) bertendensi positif, pemerintah tidak memberikan jaminan atas kepastian hukum terhadap pemegang tanda bukti sah (sertifikat), Pemerintah juga tidak bertanggung jawab atas data dan informasi yang ada di dalam sertifikat hak atas tanah. ${ }^{3}$ Data yang dimaksud disini adalah data fisik dan data yuridis yang ada di dalam Sertifikat hak atas tanah, berdasarkan Pasal 1 ayat (6) dan (7) Peraturan Pemerintah Nomor 24 Tahun 1997, Data fisik adalah keterangan mengenai letak, batas dan luas bidang tanah dan satuan rumah susun yang didaftar, termasuk keterangan mengenai adanya bangunan atau bagian bangunan di atasnya. Data yuridis adalah keterangan mengenai status hukum bidang tanah dan satuan rumah susun yang didaftar, pemegang haknya dan hak pihak lain serta beban-beban lain yang membebaninya.sedangkan informasi adalah hal hal yang menyangkut

\footnotetext{
${ }^{2}$ Urip Santoso, Pendaftaran Dan Peralihan Hak Atas Tanah (Jakarta: Prenadamedia Group, 2010).

3 Direktorat Tata Ruang dan Pertanahan Kementerian Perencanaan Pembangunan Nasional /Badan Perencanaan Pembangunan Nasional, Kajian Persiapan Perubahan Sistem Pendaftaran Tanah Publikasi Positif Di Indonesia (Jakarta: Kementerian Perencanaan Pembangunan Nasional/Badan Perencanaan Pembangunan Nasional, 2016).
} 
pendaftaran tanah tersebut,seperti surat ukur,peta pendaftaran.

Bahwa permasalahan atau konflik pertanahan yang masuk ke Mahkamah Agung semakin meningkat diperkirakan antara 60\% hingga 70\% setiap tahun dan belum terhitung kasus yang selesai ketika diputus pada tingkat pertama maupun tingkat banding. ${ }^{4}$ Berdasarkan latar belakang di atas maka penulis membuat rumusan masalah pertama bagaimana sistem pendaftaran tanah yang bisa memberikan perlindungan dan kepastian hukum bagi pemegang sertifikat hak atas tanah? Yang kedua bagaimana sistem pendaftaran tanah yang tepat diberlakukan di Indonesia untuk bisa memberikan perlindungan dan kepastian hukum kepada pemegang sertifikat hak atas tanah?

\section{METODE PENELITIAN}

Jenis penelitian yang digunakan dalam penelitian ini adalah penelitian yuridis normatif, yaitu penelitian hukum yang berasal dari penelitian kepustakaan dengan menggunakan bahan hukum primer dan bahan hukum sekunder. Penelitian hukum menurut Morris L. Cohen merupakan proses untuk mendapatkan aturan hukum pemerintah yang diterapkan dalam kehidupan masyarakat. Penelitian hukum dapat dilakukan dalam beberapa tipe, yakni doktrinal research, reform-oriented research, theoritical research dan fundamental research. ${ }^{5}$ Tipe penelitian yang digunakan dalam penelitian ini adalah tipe penelitian konflik norma adanya pertentangan peraturan yang lebih rendah dengan peraturan yang lebih tinggi. Sehubungan dengan jenis penelitian yang digunakan adalah yuridis normatif, maka penulisan penelitian ini dilakukan dengan menggunakan pendekatan perundang-undangan.Menelaah semua peraturan perundang-undangan yang bersangkut paut dengan isu hukum yang ditangani. Pendekatan konseptual beranjak dari pandangan-pandangan dan doktrin-doktrin yang berkembang dalam ilmu hukum" dan juga melalui literatur dan bahan bacaan lainya sebagai teori pendukung dari pembahasan tersebut untuk memperlancar penelitian ini

\section{ANALISIS DAN PEMBAHASAN}

\subsection{Bagaimana Sistem Pendaftaran Tanah yang bisa memberikan Perlindungan dan} Kepastian Hukum bagi Pemegang Sertifikat Hak atas Tanah

\section{A. Sistem Pendaftaran Tanah dan Sistem Publisitas Pendaftaran Tanah}

Berbicara mengenai sistem pendaftaran tanah dan sistem publisitas pendaftaran tanah, hal dasar yang patut kita ketahui terlebih dahulu ialah apa itu pendaftaran tanah dan apa guna nya pendaftaran tanah ?pendaftaran tanah merupakan pendokumentasian sebuah realita yang dapat menjadi fakta tentang kepemilikan orang atas tanah yang dimiliki nya.pendokumentasian tersebut mencakup peristiwa-peristiwa berkaitan dengan kepemilikan orang atas sebidang tanah, yang dapat dilihat orang dan sebagai alat pembuktian sebuah kepemilikan. Dan tujuan pendaftaran tanah tersebut secara sederhana dalam hal orang memerlukan tanah, secara legalitas orang tersebut mengetahui

\footnotetext{
4 Direktorat Tata Ruang dan Pertanahan Kementerian Perencanaan Pembangunan Nasional /Badan Perencanaan Pembangunan Nasional.

5 Peter Mahmud Marzuki, Penelitian Hukum, Cetakan VI (Jakarta: Prenada Media Group, 2011).
} 
cara bagaimana memperolehnya dan apa yang menjadi alat bukti nya. ${ }^{6}$ bahwa tujuan pendaftaran tanah untuk memberikan jaminan kepastian hukum yang bersifat recht $\mathrm{ka}$ daster kepada hak seseorang, maupun untuk memberikan perlindungan hukum kepada para pihak yang memperoleh tanah dengan itikad baik. ${ }^{7}$

1. Sistem Pendaftaran Tanah

Setelah mengetahui apa pendaftaran tanah dan tujuan nya seperti yang diuraikan diatas penulis akan membahas apa itu sistem pendaftaran tanah,sistem pendaftaran tanah merupakan tata cara yang dilakukan untuk adanya suatu pendaftaran tanah yang muara dari semuanya adalah membuktikan siapa yang berhak atas tanah yang didaftarkan tersebut.sistem pendaftaran tanah mempermasalahkan :apa yang didaftar,bentuk penyimpanan,dan penyajian data yuridis,serta bentuk tanda bukti haknya $^{8}$ ada dua macam sistem pendaftaran tanah yang dikenal yaitu ${ }^{9}$

a. Sistem pendaftaran akta

Dalam sistem pendaftaran akta, akta-akta itulah yang didaftar oleh Pejabat Pendaftar Tanah (PPT).Dalam sistem pendaftaran akta PPT bersifat pasif. Ia tidak melakukan pengujjian kebenaran data yang disebut dalam akta yang didaftar.

b. Sistem pendaftaran hak

Dalam sistem pendaftaran hak, setiap penciptaan hak baru dan perbuatanperbuatan hukum yang menimbulkan perubahan kemudian, juga harus dibuktikan dengan suatu akta, tetapi dalam penyelenggaraan pendaftarannya,bukan akta yang didaftarkan, melainkan haknya yang diciptakan dan perubahan-perubahannya kemudian.akta merupakan sumber datanya.

2. Sistem Publikasi Pendaftaran Tanah

Sistem publikasi, merupakan satu rangkaian dari sistem pendaftaran tanah,kelanjutan setelah didaftarkannya tanah, tersebut.sistem publikasi ini secara filosofis sejauh mana kita dapat mempercayai data tentang tanah yang didaftarkan beserta akibat hukum yang ditimbulkan nya. Pertanyaan yang timbul adalah sejauh mana orang boleh mempercayai kebenaran data yang disajikan itu ?sejauh mana hukum melindungi kepentingan orang yang melakukan perbuatan hukum mengenai tanah yang hak nya telah didaftarkan, berdasarkan data yang telah disajikan PPT atau yang tercantum dalam surat tanda bukti hak yang diterbitkannya atau didaftar oleh PPT,jika kemudian ternyata data itu tidak benar ?jawabannya terletak sistem publikasi yang dianut. ${ }^{10}$ Ada beberapa sistem publikasi yang dikenal dalam sistem pendaftaran tanah yaitu :

\footnotetext{
${ }^{6}$ Harsono Budi, "Hukum Agraria Indonesia (Sejarah Pembentukan Undang-Undang Pokok Agraria,Isi Dan Pelaksanaannya)" (Universitas Trisakti Jakarta, 2018).

7 Sahnan, Hukum Agraria Indonesia (Malang: Setara Press, 2016).

8 Budi, "Hukum Agraria Indonesia (Sejarah Pembentukan Undang-Undang Pokok Agraria,Isi Dan Pelaksanaannya)."

9 Erna Sri Wibawanti and R.Mujiyanto, Hak Atas Tanah Dan Peralihannya (Yogyakarta: Liberty, 2013).

${ }^{10}$ Budi, "Hukum Agraria Indonesia (Sejarah Pembentukan Undang-Undang Pokok Agraria,Isi Dan Pelaksanaannya)."
} 
a. Sistem Torrens

Diperkenalkan oleh Sir Robert Richard Torrens.prinsip dari sistem ini adalah manakala seorang mengklaim sebagai pemilik fee simple baik karena undang-undang atau sebab lain harus mengajukan suatu permohonan agar lahan yang bersangkutan diletakan atas nama nya. ${ }^{11}$ Permohonan tersebut diteliti dan diuji yang mana akhir dari pengujian tersebut dapat disimpulkan $;^{12}$

1) bahwa lahan yang dimohonkan didaftarkan tersebut baik dan jelas.

2) Bahwa atas permohonan tidak ada sengketa dalam pemilikan tersebut.

3) Bahwa atas permohonannya secara meyekinkan dapat diberikan.

4) Bahwa atas bukti dari alas hak tidak ada orang yang berprasangka dan berkeberatan terhadap kepemilikan pemohon.

Ada beberapa keuntungan dari sistem Torrens tersebut antara lain:13

1) Menetapkan biaya-biaya yang tak dapat diduga sebelumnya.

2) Meniadakan pemeriksaan yang berulang-ulang.

3) Meniadakan kebanyakan rekaman.

4) Secara tegas menyatakan dasar hak nya.

5) Melindungi terhadap kesulitan-kesulitan yang tidak tersebut dalam sertifikat.

6) Meniadakan (hampir tak mungkin)pemalsuan.

7) Tetap memelihara sistem tersebut tanpa menambahkan kepada taksasi yang menjengkelkan.oleh karena yang memperoleh kemanfaatan dari sistem tersebut adalah yang membayar biaya.

8) Meniadakan alas hak pajak.

9) Memberikan suatu alas hak yang abadi. Oleh karena Negara menjamin tanpa batas.

b. Sistem publisitas positif

Sistem publisitas ini menekankan apa yang tertera dalam buku tanah dan surat tanda bukti hak yang diterbitkan adalah sebagai alat bukti yang mutlak .pihak yang nama nya didalam surat tanda bukti hak tersebut, mendapatkan perlindungan yang mutlak, meskipun dikemudian hari keterangan-keterangan yang ada dalam surat tanda bukti tersebut tidak benar. Bagi mereka yang dirugikan akan diberikan kompensasi dalam bentuk lain. ${ }^{14}$

c. Sistem negatif

Sertifikat yang dikeluarkan merupakan alat bukti hak atas tanah yang kuat artinya semua keterangan dianggap benar selama tidak dibuktikan sebaliknya.apabila terbukti keterangan yang ada didalam sertifikat tersebut tidak

\footnotetext{
${ }^{11}$ A.P. Parlindungan, Pendaftaran Tanah Di Indonesia (Berdasarkan PP No 24 Tahun 1997 Dilengkapi Dengan Peraturan Jabatan Pejabat Pembuat Akta Tanah (PP No 37 Tahun 1998) (Bandung: CV. Mandar Maju, 2009).

12 Parlindungan.

${ }_{13}$ Parlindungan.

${ }^{14}$ Wibawanti and R.Mujiyanto, Hak Atas Tanah Dan Peralihannya.
} 
benar,maka sertifikat dapat dilakukan perubahan seperluanya. ${ }^{15}$

d. Sistem negatif mengandung unsur positif

Sistem negatif ,bahwa apabila keterangan yang ada didalam sertifikat tidak benar, dapat dilakukan perubahan,sedangkan unsur positifnya adanya peran aktif dari para pelaksana pendaftaran tanah.

\section{B. Analisa Sistem Publisitas Pendaftaran Tanah dilihat dari Teori Perlindungan $\mathbf{H u}-$ kum dan Teori Kepastian Hukum}

Dalam dunia ilmu, teori menenempati kedudukan yang penting.Ia memberikan sarana kepada kita untuk bisa merangkum serta memahami masalah yang kita bicarakan secara lebih baik.hal-hal semula yang tampak tersebar dan berdiri sendiri bisa disatukan dan ditunjukan kaitannya satu sama lain secara bermakna.Teori, dengan demikian memberikan penjelasan dengan cara mengorganisasikan dan mensistematiskan masalah yang dibicarakan Teori perlindungan hukum, hukum melindungi kepentingan seseorang dengan cara mengalokasikan suatu kekuasaan kepadanya untuk bertindak dalam rangka kepentingannya tersebut. Pengalokaasian kekuaasaan ini dilakukan secara terstruktur, dalam arti, ditentukan keleluasaan dan kedalamannya, kekuasaan yang demikianlah yang disebut sebagai Hak.Dengan demikian, tidak setiap kekuasaan dalam masyarakat itu bisa disebut hak, melainkan hanya kekuasaan tertentu saja yaitu yang diberikan hukum kepada seseorang. ${ }^{16}$

Teori kepastian hukum menurut Hans Kelsen, hukum adalah sebuah sistem norma, norma adalah pernyataan yang menekankan aspek seharusnya atau das sollen dengan menyertakan beberapa peraturan tentang apa yang harus dilakukan.Norma-norma adalah produk dan aksi manusia yang deliberatif.Undang-undang yang berisi aturan aturan yang bersifat umum menjadi pedoman bagi individu bertingkah laku dalam masyarakat, baik dalam hubungan dengan sesama individu maupun dalam hubungan dengan masyarakat. Aturan-aturan tersebut menjadi batasan bagi masyarakat dalam membebani atau melakukan tindakan terhadap individu adanya aturan itu dan pelaksanaan aturan tersebut menimbulkan kepastian hukum. ${ }^{17}$

a. Sistem Torrens

Didalam sistem torrens ini sistem publikasinya,peran Negara menjamin sepenuhnya pendaftaran dan penerbitan sertifikat, dan kewajiban Negara memberikan ganti rugi kepada pemilik tanah yang menderita kerugian atas kesalahan pendaftaran. ${ }^{18}$

Pendaftaran adalah segalanya dalam sistem torrens ini, karena pendaftaran tersebut merupakan prasyarat bagi sifat kebal gugatan dan yang terpenting hak atas tanah yang telah didaftar secara baik dan benar tidak mungkin digugat oleh

\footnotetext{
15 Wibawanti and R.Mujiyanto.

16 Wibawanti and R.Mujiyanto.

${ }^{17}$ Shinta Novi Wardhani, "Kekuatan Hukum Sertifikat Hak Atas Tanah Dikaitkan Dengan Kepastian Hukum Dalam Pendaftaran Tanah," Al-Qanun: Jurnal Pemikiran Dan Pembaharuan Hukum Islam 21, no. 1 (2018): 81-82, https://doi.org/https://doi.org/10.15642/alqanun.2018.21.1.61-84.

${ }^{18}$ Adrian Sutedi, Tinjauan Hukum Pertanahan (Jakarta: Pradnya Paramita, 2009).
} 
siapapun. ${ }^{19}$.namun kekebalan tersebut tidak akan diberikan kepada pemilik terdaftar jika ;ada penipuan yang melibatkan pemilik atau kuasanya ;pendaftaran tanah diperoleh dengan cara memalsukan atau memakai perangkat hukum yang tidak sah; serta bila ada hak milik atau hak lainnya diperoleh dengan melanggar hukum ${ }^{20}$

Sistem Torrens ini dari segi perlindungan hukum jika di uji dengan pisau uji teori perlindungan hukum, Negara selaku kekuasaan tertinggi menjamin penuh pendaftar yang mendaftarkan tanahnya yang merupakan prasyarat untuk kebal gugatan,unsur hukum melindungi kepentingan seseorang dengan cara mengalokasikan suatu kekuasaan kepadanya untuk bertindak dalam rangka kepentingannya tersebut menurut pendapat penulis telah terpenuhi, kewajiban negara menjamin melindungi pendaftar yang telah mendaftarkan tanah nya merupakan suatu pengalokasian kekuasaan yang diberikan oleh Negara kepada pendaftar untuk bertindak atas tanah nya tersebut merupakan "keuntungan"yang diberikan Negara.

Dan dari kepastian hukum, jika diuji dengan teori kepastian hukum, kepastian pendaftar menjadi pemilik jelas, tidak di ganggu gugat, jika ada kesalahan dalam pendaftaran tersebut maka pemilik asli mendapatkan ganti rugi unsur aturan-aturan tersebut menjadi batasan bagi masyarakat dalam membebani atau melakukan tindakan terhadap individu adanya aturan itu dan pelaksanaan aturan tersebut menimbulkan kepastian hukum.telah terpenuhi.

b. Sistem Publisitas positif

Sistem ini menggunakan sistem pendaftaran hak, jadi yang didaftarkan adalah hak nya ,bukan perbuatan hukumnya,jadi pemegang hak lah yang membuat orang menjadi pemilik atas tanah yang bersangkutan. ${ }^{21}$

Dalam sistem pendaftaran tanah positif, segala yang tercantum dalam buku pendaftaran tanah dan surat-surat tanda bukti hak yang dikeluarkan merupakan suatu hal yang bersifat mutlak, dan merupakan alat bukti yang mutlak. ${ }^{22}$

Asas yang digunakan dalam sistem publisitas positif ini adalah asas itikad baik, yang artinya orang yang memperoleh sesuatu dengan itikad baik tetap menjadi pemegang hak yang sah dari hak itu, meskipun orang yang mengalihkan hak nya itu ternyata bukan orang yang berhak. ${ }^{23}$ Pemegang hak yang sebenarnya hanya dapat menuntut kembali haknya jika dapat membuktikan bahwa orang yang memperoleh hak nya itu tidak beritikad baik. ${ }^{24}$ Dengan lain kata asas itikad baik ini masih memberikan peluang bagi pemilik sebenanrnya untuk mendapatkan tanah nya,yang syaratnya harus bisa membuktikan bahwa dirinya mempunyai itikad baik dalam

\footnotetext{
${ }^{19}$ Sutedi.

${ }^{20}$ Sutedi.

${ }^{21}$ Budi, "Hukum Agraria Indonesia (Sejarah Pembentukan Undang-Undang Pokok Agraria,Isi Dan Pelaksanaannya)."

${ }^{22}$ Sutedi, Tinjauan Hukum Pertanahan.

${ }^{23}$ Sutedi.

${ }^{24}$ Sutedi.
} 
perolehan kepemilikan tanah tersebut.

Sistem publisitas positif dari segi perlindungan hukum jika di uji dengan pisau uji teori perlindungan hukum, pendaftaran hak merupakan orang yang berhak atas tanah yang didaftarkannya bukan perbuatan hukumnya, jadi nama pendaftar yang didaftarkannlah yang mempunyai hak,unsur hukum melindungi kepentingan seseorang dengan cara mengalokasikan suatu kekuasaan kepadanya untuk bertindak dalam rangka kepentingannya tersebut menurut pendapat penulis telah terpenuhi, kewajiban negara menjamin melindungi pendaftar yang telah mendaftarkan haknya merupakan suatu pengalokasian kekuasaan yang diberikan oleh Negara kepada pendaftar untuk bertindak atas tanah nya tersebut merupakan "keuntungan"yang diberikan Negara. Dan dari kepastian hukum, jika diuji dengan teori kepastian hukum, asas itikad baik dalam sistem publisitas positif ini memnunculak kepastian huum yang jelas bagi pemilik yang beritikad baik, pemillik asli atau penerima peralihan hak.yang kuncinya wajib membuktikan penguasaan atas tanah tersebut dalam keadaan beritikad baik.unsur aturan-aturan tersebut menjadi batasan bagi masyarakat dalam membebani atau melakukan tindakan terhadap individu adanya aturan itu dan pelaksanaan aturan tersebut menimbulkan kepastian hukum.telah terpenuhi

c. Sistem Publisitas Negatif

Dalam sistem publisitas negatif, hal yang ditekankan dalam pendaftaran tanah adalah perbuatan hukum yang didaftarkan, yaitu perpindahan hak kepada pembelilah yang didaftarkan.pendaftar setelah didaftarkan tanah nya tidak mutlak sebagai pemilik, masih dimungkinkan adanya keberatan dari pihak lain atas hak tanah tersebut. biarpun sudah melakukan pendaftaran,pembeli selalu masih menghadapi kemungkinan gugatan dari orang yang dapat membuktikan bahwa dialah pemegang hak yang sebenarnya. ${ }^{25}$

Sistem publisitas Negatif dari segi perlindungan hukum jika di uji dengan pisau uji teori perlindungan hukum, pendaftar hak walaupun hak nya telah terdaftar,tetap masih tidak aman posisi nya karena setiap saat masih dapat digugat pihak yang merasa punya hak juga atas tanah tersebut.Negara dalam hal ini hanya melindungi perbuatan hukum yang dilakukan atas tanah tersebut tetapi perlindugan hukum terhadap hak yang terdaftar tidak dijamin.perlindungan hukum dalam sistem publisitas negatif ini hanya kepada siapa yang paling berhak atas tanah tersebut. ,unsur hukum melindungi kepentingan seseorang dengan cara mengalokasikan suatu kekuasaan kepadanya untuk bertindak dalam rangka kepentingannya tersebut menurut pendapat penulis telah tidak ada jaminan oleh Negara.

Dan dari kepastian hukum, jika diuji dengan teori kepastian hukum, sistem publisitas Negatif ini pendaftar yang mendaftarkan hak nya tersebut,baru mendapat kepastian hukum yang sebenaranya jika telah ada putusan hakim pada pengadilan TUN dan Pengadilan Umum, dalam hal ini putusan hakim sebagai penyaring kepas-

\footnotetext{
${ }^{25}$ Budi, "Hukum Agraria Indonesia (Sejarah Pembentukan Undang-Undang Pokok Agraria,Isi Dan Pelaksanaannya)."
} 
tian hukum. ${ }^{26}$

d. Sistem Negatif mengadung unsur Positif

Sistem publikasi ini, jika keterangan dalam sertifikat tersebut tidak benar maka akan dilakukan perubahan,tetapi dalam hal pendaftaran tanah nya peran pelaksana pendaftaran tanah aktif, sebagaimana dalam sistem publisitas positif.

Jika berdasarkan teori perlindungan hukum, sistem publikasi ini sama seperti sistem publikasi negatif dimana Negara dalam hal ini hanya melindungi perbuatan hukum yang dilakukan atas tanah tersebut tetapi perlindugan hukum terhadap hak yang terdaftar tidak dijamin.perlindungan hukum dalam sistem publisitas negatif ini hanya kepada siapa yang paling berhak atas tanah tersebut. ,unsur hukum melindungi kepentingan seseorang dengan cara mengalokasikan suatu kekuasaan kepadanya untuk bertindak dalam rangka kepentingannya tersebut menurut pendapat penulis tidak ada jaminan oleh Negara. Dan dari kepastian hukum, jika diuji dengan teori kepastian hukum, sistem publisitas Negatif ini pendaftar yang mendaftarkan hak nya tersebut,baru mendapat kepastian hukum yang sebenaranya jika telah ada putusan hakim pada pengadilan TUN dan Pengadilan Umum, dalam hal ini putusan hakim sebagai penyaring kepastian hukum ${ }^{27}$

Berdasarkan uraian diatas penulis berpendapat,bahwa sistem publisitas yang dapat memberikan perlindungan dan kepastian hukum pemegang sertifikat hak atas tanah, dalam sistem pendaftaran tanah adalah sistem publisitas positif. Menurut penulis sistem publisitas positif mempunyai asas yaitu asas itikad baik, yang mana asas ini secara garis besar melindungi pendaftar yang mendaftakan hak nya atas tanah, tetapi juga melindungi pemilik asli, yang memang medapatkan tanah tersebut dengan itikad baik, tetapi dengan suatu syarat harus dapat membuktikan itikad baik tersebut. dengan kata lain sistem publisitas positif ini masih "membuka ruang kesempatan" kepada pihak pemilik asli untuk dapat memiliki hak

1.2 Sistem Pendaftaran Tanah Yang Tepat Diberlakukan Di Indonesia Untuk Bisa Memberikan Perlindungan Dan Kepastian Hukum Kepada Pemegang Sertifikat Hak Atas Tanah

A. Sistem Pendaftaran dalam Peraturan Pemerintah Nomor 10 Tahun 1961 tentan Pendaftaran Tanah

1. Perlindungan dan Kepastian hukum Peraturan Pemerintah Nomor 10 Tahun 1961 Tentang Pendaftaran Tanah, bagi pemegang sertifikat hak atas tanah

Untuk menjamin kepastian hukum pendaftaran tanah, Peraturan Pemerintah Nomor 10 Tahun 1961, dalam kegiatan pengukuran dan pemetaan, nya mengatur prosedur-prosedur seperti; Sebelum sebidang tanah diukur, terlebih dulu diadakan: penyelidikan riwayat bidang tanah itu; dan penetapan batas-batasnya. Untuk melakukan kegiatan tersebut dibentuklah panitia yang dibentuk menteri agraria, panitia ini terdiri dari pegawai jawatan pendaftaran tanah,yang sebagai ketua dan dua anggota

\footnotetext{
${ }^{26}$ Muchtar Wahid, Memaknai Kepastian Hukum Hak Milik Atas Tanah (jakarta: Republika, 2008).

27 Muchtar Wahid.
} 
Pemerintah Desa atau lebih sebagai anggota.

Didalam menjalankan pekerjaan itu Panitia memperhatikan keterangan-keterangan yang diberikan oleh yang berkepentingan. Hasil penyelidikan riwayat dan penunjukan batas tanah yang bersangkutan ditulis dalam daftar isian yang bentuknya ditetapkan oleh Kepala Jawatan Pendaftaran Tanah dan ditandatangani oleh anggotaanggota Panitia serta oleh yang berkepentingan atau wakilnya.

Jika ada perselisihan tentang batas antara beberapa bidang tanah yang letaknya berbatasan atau perselisihan tentang siapa yang berhak atas sesuatu bidang tanah, maka Panitia berusaha menyelesaikan hal itu dengan yang berkepentingan secara damai. Jika usaha tersebut di atas gagal, maka yang berkepentingan dalam perselisihan batas maupun dalam perselisihan tentang siapa yang sesungguhnya berhak atas bidang tanah itu, dapat mengajukan hal itu kemuka hakim.

Setelah pekerjaan pengukuran dan pemetaan selesai, maka semua peta dan daftar isian yang bersangkutan ditempatkan di kantor Kepala Desa selama tiga bulan, untuk memberi kesempatan kepada yang berkepentingan mengajukan keberatan-keberatan mengenai penetapan batas-batas tanah dan isi daftar-daftar isian itu. Mengenai keberatan tersebut oleh Panitia dianggap beralasan, diadakan perubahan dalam peta maupun daftar isian yang bersangkutan. Setelah perubahan-perubahan selesai dikerjakan atau jika di dalam waktu tersebut dalam tidak diajukan keberatan maka petapeta dan daftar-daftar isian itu disahkan oleh Panitia dengan suatu berita acara, yang bentuknya ditetapkan oleh Menteri Agraria.

Setelah ada pengesahan yang ditetapkan oleh menteri agraria, maka dari tiap-tiap bidang tanah yang batas-batasnya maupun yang berhak atasnya telah ditetapkan, hak-haknya dibukukan dalam daftar buku-tanah. Untuk tiap-tiap hak yang dibukukan tersebut dibuat salinan dari buku-tanah yang bersangkutan. Untuk menguraikan tanah yang dimaksud dalam salinan buku tanah dibuat surat-ukur sebagai yang dimaksud dalam Salinan buku-tanah dan surat-ukur setelah dijahit menjadi satu bersama-sama dengan suatu kertas sampul yang bentuknya ditetapkan oleh Menteri Agraria, disebut sertifikat dan diberikan kepada yang berhak. Sertifikat adalah surattanda bukti hak yang dimaksud dalam Pasal 19 Undang-undang Pokok Agraria

Peraturan Pemerintah Nomor 10 Tahun 1961 tentang Pendaftaran Tanah, dalam hal sistem publisitas dalam pendaftaran tanah, menganut sistem publisitas negatif, hal ini dipertegas dalam penjelasan Peraturan Pemerintah Nomor 10 Tahun 1961,Pembukuan sesuatu hak dalam daftar buku-tanah atas nama seseorang tidak mengakibatkan, bahwa orang yang sebenarnya berhak atas tanah itu akan kehilangan haknya; orang tersebut masih dapat menggugat hak dari orang yang terdaftar dalam buku tanah sebagai orang yang berhak (pasal 19 ayat (2) Undang-undang Pokok Agraria). Jadi cara pendaftaran hak yang diatur dalam Peraturan Pemerintah ini tidaklah positif, tetapi negatif.

Dari uraian diatas, tentang kepastian hukum Pendaftaran Tanah berdasarkan Peraturan Pemerintah Nomor 10 Tahun 1961,penulis menganalisa ketentuan keten- 
tuan yang mengatur perlindungan dan kepastian hukum dalam Peraturan Pemerintah Nomor 10 Tahun 1961,terhadap pemegang sertifikat hak atas tanah.

a) Sistem publisitas menganut sistem publisitas negatif.

Hal pertama, yang menyangkut kepastian hukum dalam pendaftaran tanah adalah sistem publisitas yang dianut.yaitu sistem publisitas negatif. Berdasarkan pasal 19 ayat (2) huruf c UUPA menyatakan pemberian surat surat tanda bukti hak, yang berlaku sebagai alat pembuktian yang kuat. Kemudian dalam penjelasan Peraturan Pemerintah Nomor 10 Tahun 1961 menyatakan dengan tegas Pembukuan sesuatu hak dalam daftar buku-tanah atas nama seseorang tidak mengakibatkan, bahwa orang yang sebenarnya berhak atas tanah itu akan kehilangan haknya; orang tersebut masih dapat menggugat hak dari orang yang terdaftar dalam buku tanah sebagai orang yang berhak (pasal 19 ayat (2) Undang-undang Pokok Agraria). Jadi cara pendaftaran hak yang diatur dalam Peraturan Pemerintah ini tidaklah positif, tetapi negatif. Sistem publisitas negatif ini merupakan salah satu dari sistem publikasi yang dikenal di dunia selain publisitas positif. Dalam sistem publikasi negatif pada sistem pendaftaran akta, Pejabat Pendaftaran Tanah (PPT) tidak melakukan pengujian terhadap kebenaran data yang tercantum dalam akta (pasif). Akta pada sistem pendaftaran tanah berfungsi sebagai alat bukti peristiwa atau perbuatan hukum yang bersifat kuat. Setiap terjadi perubahan sertifikat tanah, maka wajib dibuatkan akta baru dan data yuridis yang diperlukan harus dicari di dalam akta-akta yang bersangkutan. Akan tetapi, untuk memperoleh data yuridis harus dilakukan title search yang dapat memakan waktu dan biaya karena menggunakan bantuan ahli. Selain itu, negara tidak menjamin bahwa data fisik dan data yuridis yang tercantum dalam sertifikat adalah benar, selama tidak dibuktikan dengan alat bukti lain. Apabila data dalam sertifikat tidak benar, baik kesalahan register ataupun penipuan, maka dapat dilakukan perubahan berdasarkan keputusan pengadilan. Namun demikian, pada sistem publikasi negatif ini, negara tidak memberikan kompensasi ganti rugi kepada pihak-pihak yang kehilangan hak atas tanahnya akibat kesalahan register ataupun penipuan. ${ }^{28}$ menurut penulis, sistem publisitas negatif yang ditegaskan dalam Peraturan Pemerintah Nomor 10 Tahun 1961 tersebut sebenarnya tidak sesuai dengan kegiatan pendaftaran tanah sebagaimana diatur dalam Peraturan Pemerintah Nomor 10 Tahun 1961 tersebut, dimana dalam hal pengukuran , pemetaan sebagaimana diatur dalam Pasal 3,4,5 dan 6 Peraturan Pemerintah Nomor 10 Tahun 1961, menurut penulis, tidak menggambarkan sistem yang dianut yaitu sistem publisitas negatif, hal tersebut terlihat dalam sistem publisitas negatif mensyaratkan Pejabat Pendaftaran Tanah (PPT) tidak melakukan pengujian terhadap kebenaran data yang tercantum dalam akta (pasif), tetapi pasal 3 ayat (2) dan (3) Peraturan Pemerintah Nomor 10 Tahun 1961 menyatakan sebelum diadakan pengukuran

\footnotetext{
${ }^{28}$ Direktorat Tata Ruang dan Pertanahan Kementerian Perencanaan Pembangunan Nasional /Badan Perencanaan Pembangunan Nasional, Kajian Persiapan Perubahan Sistem Pendaftaran Tanah Publikasi Positif Di Indonesia.
} 
dan pemetaan harus dilakukan penyelidikan atas bidang tanah tersebut dan menetapkan batas batasnya, untuk melakukan kegiatan tersebut oleh menteri agraria dibentuk sebuah panitia.kemudian dari hasil kegiatan tersebut diberikan waktu kepada para pihak yang berkeberatan atas pengukuran tersebut untuk mengajukan keberatan dan dapat diselesaikan secara damai maupun secara peradilan. Dengan ini jelas unsur pejabat pendaftaran tanah atau pemerintah tidak bersifat pasif dalam kegiatan pengukuran dan pemetaan tidak terpenuhi.

Peran Negara atau pemerintah dalam hal ini panitia, dalam hal pengukuran dan pemetaan sebagaimana diatur dalam Pasal 3,4,5,dan 6 Peraturan Pemerintah Nomor 10 Tahun 1961, telah jelas mempunyai peranan penting dalam pendaftaran tanah,tetapi karena sistem publisitas negatif yang dianut maka, peran tersebut menjadi kabur, dengan tidak dijamin nya kebenaran data fisik dan data yuridis oleh pemerintah, sebagaimana seharus nya berlaku dalam sistem publikasi negatif. Padahal telah jelas nyata dan terang dalam Peraturan Pemerintah Nomor 10 Tahun 1961 peran pemerintah dalam proses pendaftaran tanah tersebut, dan sungguh tidak ideal jika Negara tidak menjamin kebenaran data fisik dan data yuridis tersebut hanya karena sistem publisitas yang dianut adalah sistem publisitas negatif.

b) Kegiatan pendaftaran tanah

Kegiatan pengukuran pemetaan hingga penerbitan surat surat tanda bukti hak yang diatur dalam Peraturan Pemerintah Nomor 10 Tahun 1961,tidak akan terlaksana jika tidak ada peran Negara dalam hal ini pemerintah, Pasal 3,4,5, dan 6 Peraturan Pemerintah Nomor 10 Tahun 1961 tersebut mengatur prosedur pengukuran dan pemetaan, yang mana hasil dari pengukuruan yang merupakan proses dari penyelidikan tentang tanah dan penetapan batas batas, sebelum disahkan terlebih dahulu diberikan kesempatan kepada yang keberatan atas penetapan tersebut, dan jika ada akan diselesaikan secara damai,tetapi jika tidak diketmukan jalan keluar maka proses peradilan dijalankan. Jika tidak ada keberatan maka ditetapkan lah hasil berita acara hasil pengukuran dan pemetaan tersebut,dengan ditetapkan menteri agraria dan diumumkan di kantor desa selama 3 (tiga) bulan, sebelum dan dibuatkan sertifikat.

Prosedur prosedur tersebut menurut pendapat penulis, telah memberikan informasi informasi yang cukup untuk menetapkan pemohon pendaftaran tanah tersebut,memang pemilik sebenarnya, karena data fisik dan data yuridis yang didapat telah melalui proses penyelidikan dalam menetapkan nya (pasal 3 Peraturan Pemerintah Nomor 10 Tahun 1961) dan sebelum berita acara pengukuran dan pemetaan tersebut disahkan, diberi kesempatan bagi pihak pihak yang berkeberatan terhadap hasil pengukuran tersebut,jika ada keberatan maka akan diselesaikan secara musyawarah dan jika gagal proses ke depan hakim, dan status tanah sebidang tanah tersebut adalah tanah sengketa sampai terselesaikan(Pasal 3 ayat (6) Peraturan Pemerintah Nomor 10 Tahun 1961). Tetapi jika tidak ada 
keberatan maka hasil pengukuran dan pemetaan tersebut dikumpulkan di kantor desa selama 3 (tiga) bulan untuk diumukan untuk memberi kesempatan pihak pihak yang berkeberatan sebelum dibukukan dalam buku tanah dan dibuatkan sertifikat.dari proses yang dilalui ini peran Negara dalam pendaftaran tanah sudah ideal, sebagaimana hak menguasai telah dimandatkan kepada Negara, dan karenanya pemohon pendaftaran tanah mendapatkan suatu jaminan kepastian hukum hak nya terhadap sebidang tanah yang di daftarkan tersebut. tetapi hal tersbut tidak dapat terlaksana karena sistem publisitas yang dianut sistem pendaftaran tanah kita menganut sistem publisitas negatif, maka pemegang sertifikat hak atas tanah, belum secara mutlak sebagai pemilik sah, karena masih dapat diajukan keberatan keberatan dan gugatan ke Pengadilan oleh pihak pihak yang merasa mempunyai hak juga.

Bahwa Peraturan Pemerintah Nomor 10 Tahun 1961 Tentang Pendaftaran Tanah, dikaitkan dengan Perlindungan dan kepastian hukum, menurut penulis secara substansi tata cara pendaftaran tanah mempunyai perlidungan dan kepastian hukum, tetapi perlindungan dan kepastian hukum tersebut menjadi hilang, karena sistem publisitas negatif yang dianut sistem pendaftaran tanah kita yang juga amanat dari pasal 19 ayat (2) huruf c UUPA. Dimana dalam sistem publisitas negatif, Negara tidak menjamin data fisik dan data yuridis dalam sertifikat adalah benar, selama tidak dibuktikan dengan alat bukti lain yang benar maka dapat dilakukanperubahan berdasarkan keputusan pengadilan. Jadi telah jelas tidak ada perlindungan dan kepastian hukum bagi pemegang sertifikat hak atas tanah bagi pemohon pendaftaran tanah.

\section{B. Sistem Pendaftaran Tanah dalam Peraturan Pemerintah Nomor 24 Tahun 1997 Tentang Pendaftaran Tanah}

1. Analisa Ketentuan-ketentuan dalam Peraturan Pemerintah Nomor 24 Tahun 1997 tentang Pendaftaran Tanah yang berkaitan dengan perlindungan dan kepastian hukum pemegang sertifikat hak atas tanah, dilihat dari Teori Perlindungan hukum dan Teori Kepastian hukum

a. Sertifikat sebagai tanda bukti hak dan Sifat pembuktian sertifikat sebagai tanda bukti hak

Menurut analisa Penulis,mengingat perkembangan sosial ekonomi yang terjadi sekarang merupakan suatu celah Peraturan Pemerintah Nomor 24 Tahun 1997 tentang Pendaftaran Tanah tidak mempunyai kepastian hukum bagi pemegang sertifikat hak atas tanah, karena pemegang sertifikat hak atas tanah, walaupun telah mendapatkan suatu hak, yang dibuktikan denga sertifikat hak atas tanah tersebut, tetapi sewaktu-waktu dapat digugat orang kembali yang juga merasa memiliki hak atas sebidang tanah tersebut,dan hal itu secara peraturan perundang-undangan diberikan ruang untuk hal tersebut. Walapun Pasal 32 ayat (2) Peraturan Pemerintah nomor 24 Tahun 1997,merupakan perlindungan hukum 
bagi pemegang sertifikat hak atas tanah, untuk tidak dapat digugat lagi, jika selama 5 (lima) tahun sejak diterbitkan nya sertifikat hak atas tanah tersebut, maka pihak yang merasa memiliki sebidang tanah tersebut tidak dapat menggugat lagi, tetapi sistem publisitas kita menganut sistem negatif, maka Pasal 32 ayat (2) tersebut dapat diabaikan, hal ini diperkuat Pasal 19 ayat (2) huruf c Undang undang Pokok Agraria, berbunyi pemberian surat-surat tanda bukti hak, yang berlaku sebagai alat pembuktian yang kuat.yang telah di uraikan diatas.

\section{b. Sistem publikasi pendaftaran tanah menganut sistem publikasi negatif berten- densi positif}

Kembali ke pembahasan sistem publisitas negatif bertendensi positif jika melihat unsur dari teori perlindungan hukum, pemegang hak atas tanah secara bentuk produk hukum yang diterima nya, sebagai konswekuensi mendaftarkan tanah nya adalah surat bukti hak berupa sertifikat, sertifikat ini merupakan ciri sistem pendaftaran hak dalam sistem publisitas Positif, tetapi secara substansial dari sertifikat tersebut mengandung sistem publisitas negatif, dimana data yuridis dan data fisik yang tercantum didalam nya tidak dijamin kebenarannya oleh Negara. Sehingga terhadap keabsahan sertifikat karena setiap waktu mungkin dapat digugat dan dibatalkan. Bisa dikatakan unsur hukum melindungi kepentingan seseorang dengan cara mengalokasikan suatu kekuasaan kepadanya untuk bertindak dalam rangka kepentingannya tersebut tidak terpenuhi,perlindungan hukum pemegang bukti surat Sertifikat tersebut menjadi tidak ada, karena substansi dari sertifikat tersebut, baik data yuridis dan data fisik nya tidak dijamin oleh Negara, hal ini membuat pemegang sertifikat tidak mempunyai kekuasaan dan keleluasaan hak yang diberikan untuk melakukan suatu kehendak atau perbuatan hukum atas tanah yang dia kuasai.

Menurut analisa penulis Pasal 32 ayat (2) tersebut masih belum bisa memberikan perlindungan dan kepastian hukum bagi pemegang sertifikat hak atas tanah, karena ada pertentangan antara Peraturan Pemerintah Nomor 24 Tahun 1997, dengan Undang Undang Pokok Agraria, yaitu Pasal 19 ayat (2) huruf c Undang Undang Pokok Agraria, menyatakan bahwa akhir dari kegiatan pendaftaran tanah yang dilakukan oleh Pemerintah adalah pemberian surat tanda bukti hak, yang berlaku sebagai alat pembuktian yang kuat.kalimat sebagai alat pembuktian yang kuat, dalam pasal ini merujuk kepada sistem publisitas negatif, dengan demikian terjadi pertentangan antara Undang Undang Pokok Agraria dengan Peraturan Pemerintah Nomor 24 Tahun 1997 tentang pendaftaran tanah. Sebagaimana Pasal 7 ayat (2) Undang Undang Nomor 11 Tahun 2011 sebagaimana yang telah diubah dengan Undang Undang Nomor 15 Tahun 2019 Perubahan atas Undang undang Nomor 12 Tahun 2011 tentang Pembentukan Peraturan Perundang-Undangan yang berbunyi ; kekuatan hukum Peraturan Perundang-undangan sesuai dengan hierarki sebagaimana dimaksud pada ayat (1).

Dari peraturan yang lebih rendah, Pasal 32 ayat (2) Peraturan Pemerintah No- 
mor 24 Tahun 1997 ini juga, tidak dapat diterapkan, sebagaimana semangat dari sistem pendaftaran tanah yang negatif cenderung ke positif .peraturan tersebut adalah Pasal 104 Peraturan Menteri Agraria/Kepala Badan Pertanahan Nasional Nomor 9 tahun 1999 tentang Tata cara Pemberian dan Pembatalan Hak atas Tanah Negara dan Hak Pengelolaan. Dalam Pasal 104 tersebut dijelaskan dalam ayat (1) pembatalan hak atas tanah meliputi pembatalan keputusan pemberian hak, sertifikat Hak atas tanah,keputusan pemberian hak dalam rangka pengaturan penguasaan tanah. Ayat (2) mengatur pembatalan hak atas tanah sebagaimana dimaksud pada ayat (1), diterbitkan karena ada terdapat cacat hukum administrasi dalam penerbitan keputusan pemberian dan /atau sertifikat hak atas tanah nya atau melaksanakan putusan pengadilan yang telah mempunyai kekuatan hukum tetap.dalam pasal 104 ini tidak ada membatasi jangka waktu pihak-pihak lain yang merasa berkepentingan untuk menggugat hak atas tanah yang bersangkutan, hal ini telah jelas terjadi ketidak konsitenan regulasi pertanahan.

Sebagai contoh pembatalan hak tanah yang diatur dalam Peraturan Pemerintah Nomor 24 Tahun 1997 dan Peraturan Menteri Agraria/Kepala Badan Pertanahan Nasional Nomor 9 Tahun 1999 menentukan bahwa pembatalan hak kerena cacat hukum administrasi dalam penetapanya, dapat dilakukan berdasarkan atau tidak berdasarkan permohonan yang berkepentingan tanpa melalui proses Pengadilan, Pembatalan dilakukan dengan keputusan menteri. ${ }^{29}$ Dengan demikian kepastian dan perlindungan hukum bagi pemegang sertifikat hak atas tanah, belum tercapai.

\section{Kegiatan Pendaftaran Tanah untuk memberikan perlindungan dan kepastian hu- kum bagi pemegang sertifikat hak atas tanah}

penulis berpendapat untuk mendapatkan kegiatan pendaftaran tanah yang memberikan perlindungan dan kepastian hukum bagi pemegang sertifikat hak atas tanah, Indonesia harus mengubah sistem publisitas pendaftaran tanah, yang menganut sistem publisitas negatif ke sistem publisitas positif. Sistem publisitas negatif yang kita anut, menjadi pemicu sengketa agraria yang terjadi. Salah satu akar permasalahan konflik agraria disebabkan oleh sistem pendaftaran tanah yang digunakan di Indonesia berupa sistem publikasi negatif yang bertendensi positif. ${ }^{30}$

Kegiatan pendaftaran tanah sebagaimana diatur dalam Peraturan Pemerintah Nomor 24 Tahun 1997 berupa kegiatan pendaftaran tanah untuk pertama kali dan pemeliharaan data pendaftaran tanah, secara tata cara, Negara telah hadir untuk mengatur nya sebagaimana mandat Pasal 33 UUD 1945, Negara diberi hak untuk menguasai, tetapi sistem publisitas negatif yang Indonesia anut mengaburkan kehadiran Negara dalam pengaturan sistem pendaftaran tanah Indonesia. Kewajiban Negara yang muncul akibat pemberian hak untuk

\footnotetext{
${ }^{29}$ Ahmad Setiawan, Hukum Pertanahan (Pengaturan,Problematika Dan Reformasi Agraria) (Yogyakarta: LaksBang Justitia, 2019).

${ }^{30}$ Direktorat Tata Ruang dan Pertanahan Kementerian Perencanaan Pembangunan Nasional /Badan Perencanaan Pembangunan Nasional, Kajian Persiapan Perubahan Sistem Pendaftaran Tanah Publikasi Positif Di Indonesia.
} 
menguasai tersebut yaitu memberikan perlindungan dan kepastian hukum bagi pemegang sertifikat hak atas tanah menjadi kabur atau tidak konsisten dan sistem publisitas negatif memberikan pembenaran tehadap tidak dijamin nya kebenaran data fisik dan data yuridis dalam kegiatan pendaftaran tanah oleh Negara.

Hal pertama dan mendasar untuk merubah sistem publistas negatif ke sistem publisitas positif, Pasal 19 ayat (2) huruf c UUPA, peraturan perundang undangan pertama yang harus dilakukan perubahan karena bunyi Pasal 19 ayat (2) huruf c ;pemberian surat surat tanda bukti hak, yang berlaku sebagai alat pembuktian yang kuat. Kalimat alat pembuktian yang kuat merupakan ciri dari sistem publisitas negatif, untuk mengubah menjadi sistem publisitas positif, kalimatnya diubah menjadi sebagai alat pembuktian yang mutlak.

Untuk perubahan menjadi sistem publisitas positif hal yang menjadi persiapan adalah $;^{31}$

1. Amandemen Pasal 19 ayat (2) huruf c UUPA dari sifat nya kuat menjadi mutlak.

2. Amandemen pasal 19 ayat (1) UUPA, peraturan pelaksana pendaftaran tanah berbentuk undang undang.

3. Meningkatkan Peraturan Pemerintah Nomor 24 Tahun 1997 menjadi Undang undang.

4. Mengefektifkan penerapan oleh hakim pasal 32 ayat (2) Peraturan Pemerintah Nomor 24 Tahun 1997

5. Meningkatkkan program PTSL dengan pemetaan partisip

\section{Pasal 33 ayat (3) Undang Undang Dasar 1945, sebagai fondasi dalam Perlindungan dan Kepastian Hukum Pendaftaran Tanah}

UUPA merupakan pelaksanaan Pasal 33 ayat (3) Undang undang Dasar 1945 sebagaimana dinyatakan dalam pasal 2 ayat (1) UUPA, yaitu atas dasar ketentuan Pasal 33 ayat (3) Undang undang dasar 1945 dan hal-hal sebagai yang dimaksud dalam Pasal 1, bumi air dan ruang angkasa termasuk kekayaan alam yang terkandung didalam nya itu pada tingkatan tertinggi dikuasai oleh Negara sebagai organisasi kekuasaan seluruh rakyat ${ }^{32}$ Pasal 33 ayat (3) Undang undang Dasar 1945, yang berbunyi ; bumi, air dan kekayaan alam yang terkandung di dalam nya dikuasai oleh Negara dan dipergunakan untuk sebsarbesarnya kemakmuran rakyat.Secara konstitusional Negara diberikan kuasa untuk menguasai seluruh areal wilayah Negara kesatuan republik Indonesia, yang tujuan nya digunakan semata mata untuk kemakmuran rakyat Indonesia. Sebagai suatu norma kewenangan (bevoegdheidnorm), Pasal 33 ayat (3) tersebut telah mengatribusikan kewenangan kepada subjek hukum, dalam hal ini Negara, untuk melakukan perbuatan hukum terhadap sumber daya alam (bumi,air,serta kekayaan alam yang terkandung di dalamnya). ${ }^{33}$

Bahwa dengan demikian bumi air dan kekayaan alam, secara de jure dikuasai oleh

\footnotetext{
${ }^{31}$ Ana Silviana, "Komparisi Sistem Publikasi Positif \& Negatif Dalam Pendaftaran Tanah Recht Kadaster," in Power Point Seminar Pertanahan (Semarang, 2020), 15.

32 Santoso, Pendaftaran Dan Peralihan Hak Atas Tanah.

${ }^{33}$ Muhammad Ilham Arisaputra, Reforma Agraria Di Indonesia (Jakarta: Sinar Grafika, 2015).
} 
Negara, secara kewenangan apapun perbuatan perbuatan hukum yang dilakukan terhadap bumi, air dan serta kekayaan alam oleh rakyat Indonesia, wajib diketahui oleh Negara, dan Negara lah yang berhak menentukan siapa saja yang berhak melakukan perbuatan hukum atas bumi ,air serta kekayaan alam yang terkandung didalamnya. Konsekuensi dari hal tersebut Negara wajib memberikan perlindungan dan kepastian hukum bagi rakyat Indonesia.

Hak menguasai Negara tersebut secara jelas diatur dalam Pasal 2 ayat (2) UUPA, dan yang berkaitan dengan hubungan hukum antara orang dan perbuatan hukum terhadap bumi, air dan kekayaan alam lainnya diatur dalam pasal 2 ayat (2) huruf c yang berbunyi menentukan dan mengatur hubungan hubungan hukum antara orang orang dan perbuatan perbuatan hukum yang mengenai bumi, air dan ruang angkasa. Secara konkrit nya kewenangan hak menguasai Negara pasal 2 ayat (2) huruf c tersebut adalah ;

a. Mengatur pelaksanaan pendaftaran tanah diseluruh wilayah Negara Republik Indonesia.(Pasal 19 UUPA Jo Peraturan Pemerintah Nomor 24 Tahun 1997 tentang pendaftaran tanah)

Bahwa telah jelas kedudukan Negara dalam hal ini hak menguasai Negara dimana UUPA telah mewujudkan secara konkrit kewenangan tersebut, dan amanat dari Pasal 33 ayat (3) Undang undang Dasar 1945, sudah terlaksana. Dihubungankan dengan sistem pendaftaran tanah di Indonesia yang ideal memberikan perlindungan dan kepastian hukum bagi pemegang sertifikat hak atas tanah, maka Pasal 33 ayat (3) ini merupakan fondasi penting, untuk menentukan arah regulasi pendaftaran tanah yang mampu memberikan perlindungan dan kepastian hukum tersebut.Sebelum mengatur yang lebih teknis lagi,mengenai pendaftaran tanah, hal yang paling penting terlebih dulu adalah memperjelas posisi Negara dalam pendaftaran tanah tersebut. Pasal 33 ayat (3) Undang Undang Dasar 1945, telah jelas nyata dan terang, bahwa Negara mempunyai kewenangan penuh untuk mengatur bumi air dan ruang angkasa diwilayah Negara kesatuan republik Indonesia, yang tujuan nya semata mata untuk kepentingan dan kemakuran rakyat Indonesia. Secara konstitusional hak menguasai atas tanah diberikan kepada Negara.

Dengan diberikan nya kewenangan hak menguasai Negara atas tanah tersebut, maka peran Negara dalam kegiatan pendaftaran tanah di indonseia, merupakan penentu berhak atau tidak nya seseorang untuk memiliki hak atas tanah yang akan didaftarkan nya. Dengan hak yang dipunyai Negara tersebut, maka Negara mempunyai kewajiban untuk memberikan perlindungan dan kepastian hukum bagi rakyat yang mendaftarakan tanah nya tersebut, yang merupakan hak bagi rakyat Indonesia yang mendaftarkan tanah nya.

E. Pasal 19 Undang-Undang Nomor 5 Tahun 1960 sebagai Dasar Hukum Pengaturan Pendaftaran Tanah

Pasal 19 UUPA ini merupakan landasan hukum terbentuknya Peraturan Pemerintah Nomor 24 Tahun 1997 Tentang Pendaftaran tanah.Untuk dapat mewujudkan sistem pendaftaran tanah yang memberikan perlindungan dan kepastian hukum bagi pemegang sertifikat hak atas tanah, Pasal 19 UUPA perlu ditelaah kembali untuk mengakomodir sistem pendaftaran tanah tersebut.

Sebagaimana disebutkan dalam pasal 19 ayat (2) huruf c yang berbunyi ; "pemberian 
surat-surat tanda bukti hak, yang berlaku sebagai alat pembuktian yang kuat".Hal ini berbicara tentang sistem publikasi dalam pendaftaran tanah. Sistem publikasi dalam pendaftaran tanah ada 2 (dua) jenis yaitu sistem publikasi positif dan sistem publikasi negatif, perbedaan kedua sistem publikasi ini terletak pada jenis sistem pendaftaran nya, sistem publikasi positif selalu menggunakan sistem pendaftaran hak (registration of titles), sedangkan sistem publikasi negatif selalu menggunakan sistem pendaftaran akta (registration of deeds) $)^{34}$

Kalimat berlaku "sebagai alat pembuktian yang kuat",hal ini mencerminkan sistem publisitas yang dianut oleh pendaftaran tanah kita adalah sistem publisitas negatif, yang mana dalam sistem pendaftaran ini kebenaran isi data yuridis dan data fisik surat-surat tanda hak, tidak dijamin kebenarannya oleh Negara.

Tetapi unsur positif dalam Pasal 32 ayat (2) ini belum menjamin perlindungan dan kepastian hukum bagi pemegang surat surat tanda hak, karena pengaturan unsur positif ini hanya ada di dalam Peraturan Pemerintah Nomor 24 Tahun 1997 yang mana secara hirarki tata urutan perundang undangan Peraturan Pemerintah ini dibawah dari pada undang undang, dalam hal ini UUPA lebih tinggi kedudukan nya, sehingga tetap surat surat tanda bukti hak tersebut bersifat sebagai pembuktian yang kuat, merupakan salah satu ciri sistem publisitas negatif, yang mana Negara tidak menjamin kebenaran data fisik dan data yuridis yang tercantum dalam surat tanda bukti hak .jika ada keberatan dan atau gugatan terhadap surat surat tanda bukti hak tersebut setiap saat mengenyampingkan Pasal 32 ayat (2). Dengan demikian Negara tidak dapat memberikan perlindungan terhadap produk hukum yang telah dikeluarkan nya sendiri dengan demikian sebenarnya jaminan perlindungan dan kepastian hukum pemegang hak atas tanah belum dapat terlaksana dengan baik.

Melihat realita dan fakta tersebut, untuk mewujudkan suatu sistem pendaftaran tanah yang tepat diberlakukan untuk bisa memberikan perlindungan dan kepastian hukum bagi pemegang sertifikat hak atas tanah, perlu perubahan yang mendasar yaitu mengubah Pasal 19 ayat (2) huruf c, UUPA,yang berbunyi pemberian surat-surat tanda bukti hak, yang berlaku sebagai alat pembuktian yang kuat,kalimat "sebagai alat pembuktian yang kuat,"dirubah menjadi "sebagai alat pembuktian yang mutlak".Dengan demikian sistem publisitas pendaftaran tanah kita menjadi sistem publisitas positif,yang mana surat-surat tanda bukti hak tersebut bersifat mutlak tidak dapat diganggu gugat.dengan demikian perlindungan dan kepastian hukum pemegang sertifikat hak atas tanah menjadi jelas nyata dan terang Perubahan sistem Publisitas, dari Publisitas Negatif bertendensi Positif, menjadi sistem Publistas Positf

Didalam pendaftaran tanah, dikenal 2 (dua) macam sistem publistas yaitu sistem publisitas Negatif dan sistem Publisitas positif .Ciri ciri sistem publikasi negatif dalam pendaftaran tanah, adalah ;35

a. Sistem pendaftaran tanah menggunakan sistem pendaftaran akta (registration of deed). ${ }^{36}$

\footnotetext{
${ }^{34}$ Setiawan, Hukum Pertanahan (Pengaturan,Problematika Dan Reformasi Agraria).

${ }^{35}$ Santoso, Pendaftaran Dan Peralihan Hak Atas Tanah.

${ }^{36}$ Santoso.
} 
b. Sertifikat yang diterbitkan sebagai tanda bukti hak bersifat kuat yaitu data fisik dan data yuridis yang tercantum dalam sertifikat dianggap benar sepanjang tidak dibuktikan sebaliknya oleh alat bukti lain. Sertifikat bukan sebagai satu-satunya tanda bukti hak. $^{37}$

c. Negara sebagai pendaftar tidak menjamin bahwa data fisik dan data yuridis dalam pendaftaran tanah adalah benar. ${ }^{38}$

d. Dalam sistem publikasi ini menggunakan lembaga kadaluwarsa (acquisitive verjaring atau adverse possessive). ${ }^{39}$

e. Pihak lain yang dirugikan atas diterbitkannya sertifikat dapat mengajukan keberatan kepada penyelenggara pendaftaran tanah untuk membatalkan sertifikat ataupun gugatan ke pengadilan untuk meminta agar sertifikat dinyatakan tidak sah. ${ }^{40}$

f. Petugas pendaftaran tanah bersifat pasif, yaitu hanya menerima apa yang dinyatakan oleh pihak yang meminta pendaftaran tanah. ${ }^{41}$

Kelebihan dari sistem publistas negatif adalah, pihak lain yang dirugikan atas diterbitkan sertifikat dapat mengajukan keberatan kepada penyelenggara pendaftaran tanah untuk membatalkan sertifikat. Sedangkan kekurangan nya sistem ini adalah pejabat pendaftaran tanah bersifat pasif, karena tidak mendukung keakuratan dan kebenaran data dalam sertifikat, dan mekanisme kerja pejabat pendaftaran tanah kurang transparan, sehingga kurang dapat dipahami oleh masyarakat awam. ${ }^{42}$

Sistem publikasi positif dalam sistem pendaftaran tanah (registration of titles) dikenal sebagai Sistem Torrens. Sistem Torrens (The Real Property Art) berasal dari Australia Selatan. Kata "Torrens" merujuk pada nama penemu sistem pendaftaran ini, yaitu Robert Richard Torrens pada tahun 1858 . Sistem publikasi positif merupakan perbaikan atau penyempurnaan dari sistem pendaftaran sebelumnya. Perbaikan kualitas sistem pendaftaran tanah ini ditunjukkan dengan adanya kemudahan bagi para pemilik tanah untuk memperoleh data yuridis tanpa harus melakukan title search pada akta-akta yang ada serta memberikan kepastian hukum pada tanah yang didaftarkan. ${ }^{43}$

Ciri-ciri sistem publisitas Positif dalam pendaftaran tanah adalah $;{ }^{44}$

a. Sistem pendaftaran tanah menggunakan sistem pendaftaran hak (registration of titles). ${ }^{45}$

b. Sertifikat yang diterbitkan sebagai tanda bukti hak bersifat mutlak, yaitu data fisik dan data yuridis yang tercantum dalam sertifikat tidak dapat diganggu gugat dan memberi-

\footnotetext{
${ }^{37}$ Santoso.

${ }^{38}$ Santoso.

39 Santoso.

40 Santoso.

${ }^{41}$ Santoso.

${ }^{42}$ Setiawan, Hukum Pertanahan (Pengaturan,Problematika Dan Reformasi Agraria).

${ }^{43}$ Direktorat Tata Ruang dan Pertanahan Kementerian Perencanaan Pembangunan Nasional /Badan Perencanaan Pembangunan Nasional, Kajian Persiapan Perubahan Sistem Pendaftaran Tanah Publikasi Positif Di Indonesia.

${ }^{44}$ Santoso, Pendaftaran Dan Peralihan Hak Atas Tanah.

45 Santoso.
} 
kan kepercayaan yang mutlak pada buku tanah. ${ }^{46}$

c. Negara sebagai pendaftar menjamin bahwa data fisik dan data yuridis dalam pendaftaran tanah adalah benar. ${ }^{47}$

d. Pihak ketiga yang memperoleh tanah dengan itikad baik mendapatkan perlindungan hukum yang mutlak. ${ }^{48}$

e. Pihak lain yang dirugikan atas diterbitkannya sertifikat mendapatkan kompensasi dalam bentuk lain. ${ }^{49}$

f. Dalam pelaksanaan pendaftaran tanah membutuhkan waktu yang lama, petugas pendaftaran tanah melaksanakan tugasnya dengan sangat teliti, dan biaya yang relatif besar. ${ }^{50}$

Kelebihan dari sistem publikasi positif ini adalah, pihak ketiga yang memperoleh tanah dengan itikad baik mendapatkan perlindungan hukum yang mutlak (indifesible) dan pihak lain yang dirugikan atas diterbitkannya sertifikat tanah mendaptkan kompensasi dalam bentuk lain. ${ }^{51}$

Sudikno Mertokusumo menyatakan bahwa kebaikan dari sistem publikasi positif adalah ; adanya kepastian dari buku tanah yang bersifat mutlak;pelaksana pendaftaran tanah bersifat aktif dan teliti;mekanisme kerja dalam penerbitan sertifikat hak atas tanah mudah dimengerti orang lain. ${ }^{52}$

Kekurangan dari sistem publisitas positif ini adalah waktu yang sangat lama karena pelaksanaan pendaftaran tanah bersifat aktif dan teliti, pemilik hak atas tanah yang sebenarnya akan kehilangan hak, wewenang pengadilan diletakan dalam wewenang administratif karena penerbitan sertifikat tidak dapat diganggu gugat nya, yaitu sebelum sistem ini berlaku, maka proses penyelesaian sengketa-sengketa pertanahan yang ada, harus diselesaikan terlebih dahulu.

Bahwa dari uraian diatas yang membahas tentang sistem publisitas positif baik dari segi keuntungan diberlakukan nya sistem tersebut,kekurangan nya juga penulis bahas agar penelitian ini memberikan gambaran secara utuh sistem publisitas positif tersebut, sehingga bisa menjadi bahan pertimbangan .selain itu faktor-faktor diluar dari keuntungan dan kerugian sistem tersebut, juga dibahas faktor lain yang bisa muncul ketika perubahan sistem publisitas positif tersebut diberlakukan.

Dengan demikian sistem pendaftaran tanah yang tepat diberlakukan di Indonesia untuk bisa memberikan perlindungan dan kepastian hukum kepada pemegang sertifikat hak atas tanah, adalah sistem pendaftaran tanah yang menganut sistem publistas positif. Dengan menganut sistem publisitas positif ini, maka kegiatan pendaftaran tanah dan pemeliharaan data pendaftaran tanah dapat maksimal ,memberikan perlindungan dan kepastian hukum

\footnotetext{
46 Santoso.

${ }^{47}$ Santoso.

${ }^{48}$ Santoso.

${ }^{49}$ Santoso.

${ }^{50}$ Santoso

${ }^{51}$ Setiawan, Hukum Pertanahan (Pengaturan,Problematika Dan Reformasi Agraria).

${ }^{52}$ Santoso, Pendaftaran Dan Peralihan Hak Atas Tanah.
} 
bagi pemegang sertifikat hak atas tanah Dalam menerapkan sistem publikasi positif, negara-negara tersebut juga menerapkan konsep indefeasible dan indemnity sebagai bentuk pemberian kompensasi ganti rugi atas kesalahan dalam sertifikasi hak atas tanah. ${ }^{53}$

Dua hal penting dalam sistem Publisitas positif agar dapat berjalan dengan baik yaitu perlindungan hukum yang mutlak serta kompensasi ganti rugi,kedua hal tersebut merupakan solusi yang tepat dan bijaksana dalam kita melihat penerapan pelaksanaan pendaftaran tanah yang mempunyai perlindungan dan kepastian hukum bagi pemegang hak atas tanah.

Konsep perlindungan hukum yang mutlak (indefeasible) dalam pendaftaran tanah sangatlah penting untuk menjamin pemegang sertifikat hak atas tanah,tidak kehilangan hak nya dan dapat dikatakan sesuatu yang wajib dalam sistem publisitas positif. Hukum "indefeasibile" merupakan pusat atau hal penting yang harus ada dalam sistem pendaftaran publikasi positif. Hukum indefeasible didasari oleh tiga prinsip utama yaitu $;^{54}$

a. Prinsip pertama adalah "prinsip cermin (mirror principle)". Prinsip ini mengharuskan hasil pendaftaran tanah dapat mencerminkan fakta-fakta terkini dari hak kepemilikan tanah secara akurat dan lengkap, baik pengalihan hak atas tanah, hipotek tanah, sewa tanah, atau tanah hasil perjanjian. Seluruh infromasi tanah harus dimasukkan ke dalam sertifikat tanah dan sistem online agar dapat dilihat oleh seluruh masyarakat. ${ }^{55}$

b. Prinsip kedua adalah "prinsip tabir (curtain principle)". Prinsip ini menyatakan bahwa sebuah tabir digunakan pada register untuk memberikan kepercayaan kepada pembeli (purchaser). Dalam hal ini pembeli tidak perlu menyelidiki atau mencari kembali sejarah atau riwayat masa lalu kepemilikan tanah seperti yang telah tergambar pada register, serta kepemilikan tanah tidak perlu dibuktikan dengan dokumen yang rumit dan panjang. ${ }^{56}$

c. Prinsip ketiga adalah "prinsip asuransi (insurance principle)". Prinsip ini menjelaskan tentang penyediaan kompensasi atau jaminan pada sistem pendaftaran hak (publikasi positif). Dalam hal ini, apabila register terbukti tidak benar mengenai tanah yang didaftarkan, maka pemerintah harus memberikan kompensasi atau ganti rugi terhadap para pendaftar tanah yang telah dirugikan. ${ }^{57}$

Hal kedua yang sama penting nya dalam sistem publisitas positif adalah jaminan

\footnotetext{
${ }^{53}$ Direktorat Tata Ruang dan Pertanahan Kementerian Perencanaan Pembangunan Nasional /Badan Perencanaan Pembangunan Nasional, Kajian Persiapan Perubahan Sistem Pendaftaran Tanah Publikasi Positif Di Indonesia.

${ }^{54}$ Direktorat Tata Ruang dan Pertanahan Kementerian Perencanaan Pembangunan Nasional /Badan Perencanaan Pembangunan Nasional.

${ }^{55}$ Direktorat Tata Ruang dan Pertanahan Kementerian Perencanaan Pembangunan Nasional /Badan Perencanaan Pembangunan Nasional.

${ }^{56}$ Direktorat Tata Ruang dan Pertanahan Kementerian Perencanaan Pembangunan Nasional /Badan Perencanaan Pembangunan Nasional.

${ }^{57}$ Direktorat Tata Ruang dan Pertanahan Kementerian Perencanaan Pembangunan Nasional /Badan Perencanaan Pembangunan Nasional.
} 
kompensasi atas kesalahan sertifikasi hak atas tanah. Ada dua jenis jaminan ganti rugi, yaitu immediate indefeasible dan deffered indefeasible. Immediate indefeasible adalah pembuatan sistem kepemilikan tanah melalui registrasi atau pendaftaran hak atas tanah yang dirancang untuk melindungi pihak yang tidak bersalah seperti pembeli tanah maupun pemberi sewa. ${ }^{58}$ Dengan kata lain, konsep immediate indefeasible adalah melindungi pihak yang memiliki hak atas tanah saat ini, meskipun proses kepemilikan atas tanah diperantara oleh seorang penipu atau dilakukan dengan cara penipuan. ${ }^{59}$ Bagi pihak yang dirugikan atas kehilangan tanahnya (pemilik asli), maka akan memperoleh jaminan ganti rugi dari pemerintah Sementara itu, deffered indefeasible dicontohkan melalui kasus tiga pihak, yaitu pemilik asli tanah, pemilik tanah kedua yang memeperoleh tanah dari seorang penipu, dan pemilik ketiga sebagai pihak yang memperoleh tanah dengan itikad baik tanpa mengetahui bahwa peralihan tanah dari pemilik asli kepada pemilik kedua diperantara oleh seorang penipu (pemilik tangguhan) ${ }^{60}$ Pada konsep ini, hukum pertanahan melindungi pemilik asli dan pemilik ketiga. Perlindungan kepada pemilik asli terjadi ketika pemilik kedua yang memperoleh tanah dari seorang penipu mendapatkan klaim dari pemilik asli, maka hukum pertanahan akan memihak pada pemilik asli dan hak kepemilikan atas tanah akan kembali kepada pemilik asli. ${ }^{61}$ Sedangkan, pemilik kedua mendapatkan ganti rugi dari pemerintah. Sementara, perlindungan kepada pemilik ketiga terjadi ketika pemilik ketiga memperoleh tanah dari pemilik kedua (tanpa mengetahui bahwa pengalihan hak atas tanah dari pemilik asli kepada pemilik kedua diprakarsai oleh penipu). Kemudian pemilik ketiga mendapatkan klaim dari pemilik asli (pemilik pertama). Dalam hal ini, hukum pertanahan akan memihak pada pemilik ketiga dan hak kepemilikan atas tanah tetap menjadi milik pemilik ketiga. ${ }^{62}$

Bahwa melihat fakta fakta ini, terjadi inkonsistensi regulasi pertanahan antara peraturan yang lebih tinggi dan yang lebih rendah, tidak seirama dan saling bertentangan, karena nya perlindungan dan kepastian hukum bagi pemegang hak atas tanah menjadi tidak jelas.

Sistem publisitas negatif bertendensi positif yang dianut sistem pendaftaran tanah di Indonesia, seperti yang diuraikan diatas, tidak dapat memberikan perlindungan dan kepastian hukum bagi pemegang sertifikat hak atas tanah, untuk itu sudah saat nya Indonesia dapat melakukan perubahan sistem tersebut menjadi sistem publisitas positif .

Sistem publisitas positif, seperti yang telah diuraikan diatas, dari segi perlindungan dan kepastian hukum, sudah dapat dicapai. Dengan sistem surat surat tanda hak yang

\footnotetext{
${ }^{58}$ Direktorat Tata Ruang dan Pertanahan Kementerian Perencanaan Pembangunan Nasional/Badan Perencanaan Pembangunan Nasional.

${ }^{59}$ Direktorat Tata Ruang dan Pertanahan Kementerian Perencanaan Pembangunan Nasional /Badan Perencanaan Pembangunan Nasional.

${ }^{60}$ Direktorat Tata Ruang dan Pertanahan Kementerian Perencanaan Pembangunan Nasional /Badan Perencanaan Pembangunan Nasional.

${ }^{61}$ Direktorat Tata Ruang dan Pertanahan Kementerian Perencanaan Pembangunan Nasional/Badan Perencanaan Pembangunan Nasional.

${ }^{62}$ Direktorat Tata Ruang dan Pertanahan Kementerian Perencanaan Pembangunan Nasional/Badan Perencanaan Pembangunan Nasional.
} 
mempunyai kekuatan hukum mutlak,dimana data fisik dan data yuridis dijamin oleh Negara memberikan perlindungan dan kepastian hukum, pemberian kompensasi ganti rugi,dengan menggunakan sistem immediate indefeasible dan deffered indefeasible terhadap pemilik asli yang tanah nya telah diberi hak atas nama orang lain,ini merupakan cara untuk penyelesaian sengketa pertanahan, yang lebih pasti dari segi keadilan, proses yang tidak panjang, seperti penyelesaian dalam sistem publisitas negatif yang proses penyelesaian nya lewat jalur peradilan, yang mempunyai tahapan tahapan yang panjang sampai mendapatkan keputusan yang mempunyai kekuatan hukum tetap.

Perubahan dari sistem publisitas negatif ke sistem publisitas positif, posisi hak dan kewajiban Negara menjadi jelas dan tegas, dimana hak menguasai Negara sepenuhnya dapat dijalankan dan kewajiban

Negara menjamin perlindungan dan kepastian hukum seperti yang diamanatkan Undang Undang Dasar 1945 dan UUPA dapat dirasakan oleh setiap rakyat Indonesia.

F. Sistem pendaftaran tanah yang memberikan perlindungan dan kepastian hukum bagi pemegang sertifikat hak atas tanah.

Sistem publisitas positif, menurut penulis, sangat ideal untuk diberlakukan dalam sistem pendaftaran tanah Indonesia, telah di uraikan diatas bagaimana sistem publisitas positif dipakai negara-negara di dunia, dalam sistem pendaftaran tanah nya, yang secara perlindungan dan kepastian hukum bagi pemegang sertifikat hak atas tanah, sudah terpenuhi.

Sistem publisitas positif memberikan kepada pemegang sertifikat hak atas tanah, suatu hak yang sifatnya mutlak, dalam artian tidak dapat diganggu gugat, lagi oleh pihak lain, yang mengaku mempunyai hak juga atas sebidang tanah yang telah disertifikat tersebut. jaminan pemegang hak atas tanah apabila telah bersertifikat bersifat mutlak,Negara menjamin kebenaran data fisik dan data yuridis .Apabila ada pihak pihak yang keberatan atas diterbitkan nya sertifikat hak atas tanah tersebut, maka peran Negara disini akan melakukan pemeriksaan tentang hal tersebut apabila benar maka Negara akan memberi kompensasi atas kesalahan dalam pemberian hak atas tanah, tersebut.Disini kita lihat bahwa subyek hukum yang terdaftar dalam sertifikat hak atas tanah tersebut, mendapat suatu kepastian hukum, untuk melakukan perbuatan perbuatan hukum atas sebidang tanah yang telah diberikan hak tersebut . Dengan demikian unsur berperilaku sesuai pola yang ditentukan, yang merupakan unsur dari teori kepastian hukum telah terpenuhi.

Adanya perlindungan dan kepastian hukum yang jelas dalam sistem publisitas positif tersebut. maka sudah sepatutnya lah sistem pendaftaran tanah Indonesia beralih ke sistem publisitas positif.

Hal yang paling dasar untuk menerapkan sistem publisitas positif dalam sistem pendaftaran tanah di Indonesia dengan mengubah berbagai peraturan perundang -undangan yang berkaitan dengan pendaftaran tanah. Hal-hal yang harus ada dalam isi undang-undang pendaftaran tanah yang baru, antara lain ; ${ }^{63}$

a. Penerapan tiga prinsip utama di dalam hukum indefeasible.

\footnotetext{
${ }^{63}$ Direktorat Tata Ruang dan Pertanahan Kementerian Perencanaan Pembangunan Nasional /Badan Perencanaan Pembangunan Nasional.
} 
b. Penentuan jenis kompensasi ganti rugi atas kesalahan dalam register (immediate indefeasible atau deffered indefeasible),

c. Penentuan tanah yang dapat didaftarkan atau dilegalisasikan. Tanah-tanah ini berupa tanah yang diperoleh sebelum 17 Agustus 1945 (sebelum Indonesia merdeka), tanah waris dari pendudukan penjajah, tanah wakaf yang sebelumnya dimiliki secara mutlak dan secara sah telah diberikan, dan sebagainya.

Perubahan pasal 19 ayat 2 huruf c UUPA yang berbunyi Pemberian surat-surat tanda bukti hak, yang berlaku sebagai alat pembuktian yang kuat,merupakan langkah pertama untuk mengganti sistem publisitas negatif ke sistem publisitas positif, karena UUPA merupakan peraturan induk tentang pokok keagrarian,Pasal 19 ayat (2) huruf c tersebut di ubah menjadi Pemberian surat-surat tanda bukti hak, yang berlaku sebagai alat pembuktian yang mutlak,kata mutlak disini, merupakan ciri dari sistem publikasi positif.Pemegang surat tanda bukti hak dijamin perlindungan dan kepastian hukum oleh Negara dalam hal menggunakan tanah yang telah di daftarkan tersebut.

Penambahan pasal baru dalam UUPA, untuk mendukung perubahan sistem publisitas positif tersebut yaitu berkaitan tentang peraturan perundang-undangan yang mengatur hal hal yang belum diatur dalam UUPA, hendaknya peraturan tersebut selaras dan sesuai dengan ketentuan UUPA, tidak bertentangan dengan UUPA .Prinsip prinsip yang dikandung oleh undang-undang sektoral yang lahir tersebut seharusnya sama dan sinkron antara satu sama lainya, terkhusus dengan UUPA sebagai undang undang pokok agrarian pertama yang lahir di Indonesia. ${ }^{64}$

Sistem pendaftaran tanah, yang menganut sistem publisitas positif juga memberikan solusi dalam menyelesaikan sengketa pertanahan. Sengketa tanah dapat berupa sengketa administratif,sengketa perdata,serta sengketa pidana terkait kepemilikan, transaksi, pendaftaran penjaminan, pemanfaatan penguasaan, dan sengketa hak ulayat. ${ }^{65}$ Solusi yang diberikan sistem publisitas positif menyangkut sengketa pertanahan adalah dengan pemberian ganti rugi dengan 2 (dua) mekanisme yaitu;

a. Immediate indefeasible adalah pembuatan sistem kepemilikan tanah melalui registrasi atau pendaftaran hak atas tanah yang dirancang untuk melindungi pihak yang tidak bersalah seperti pembeli tanah maupun pemberi sewa. Mekanisme yang pertama ini, dengan jelas melindungi hak dari pihak yang sekarang memiliki hak atas tanah tersebut, sedangkan pemilik asli, akan mendapat kompensasi ganti rugi dari pemerintah. ${ }^{66}$

b. Deffered indefeatsible yaitu ; Pada konsep ini, hukum pertanahan melindungi pemilik asli dan pemilik ketiga. Perlindungan kepada pemilik asli terjadi ketika pemilik kedua yang memperoleh tanah dari seorang penipu mendapatkan klaim dari pemilik asli, maka hukum pertanahan akan memihak pada pemilik asli dan hak kepemilikan atas tanah akan kembali kepada pemilik asli. Sedangkan, pemilik kedua mendapatkan ganti rugi dari pemerintah. Sementara, perlindungan kepada pemilik ketiga terjadi ketika pemilik

\footnotetext{
${ }^{64}$ Arisaputra, Reforma Agraria Di Indonesia.

${ }^{65}$ Arisaputra.

${ }^{66}$ Arisaputra.
} 
ketiga memperoleh tanah dari pemilik kedua (tanpa mengetahui bahwa pengalihan hak atas tanah dari pemilik asli kepada pemilik kedua diprakarsai oleh penipu). Kemudian pemilik ketiga mendapatkan klaim dari pemilik asli (pemilik pertama). Dalam hal ini, hukum pertanahan akan memihak pada pemilik ketiga dan hak kepemilikan atas tanah tetap menjadi milik pemilik ketiga ${ }^{67}$

Dua mekanisme ganti rugi ini menurut penulis, dapat memberikan solusi atau jalan keluar terhadap sengketa pertanahan yang terjadi pada saat ini.Jika dalam sistem publistas negatif penyelesaian sengketa pertanahan ini menggunakan cara litigasi yaitu gugatan ke pengadilan, yang menyita banyak waktu, sampai menunggu putusan yang mempunyai kekuatan hukum tetap, maka dalam konsep ganti rugi ini lebih efektif,dan terasa nyata hadirnya Negara dalam menyelesaian sengketa pertanahan.Dalam hal ini Negara memberikan keadilan bagi para pihak yang berkaitan dengan sengketa tanah tersebut.

Bahwa sistem publisitas positif juga mempunyai kekurangan dalam penerapannya,hal ini juga menjadi bahan pertimbangan penulis untuk juga meneliti kekurangan sistem publisitas positif ini. Dari menganalisa kekurangan dari sistem publisitas positif ini, kita mendapat gambaran secara utuh apakah sistem publisitas positif ini dapat "lulus uji" dan menjadi jawaban solusi dari sistem pendaftaran tanah di Indonesia.

Ada 3 (tiga) kekurangan yang dimiliki sistem publisitas positif yaitu ;

a. Waktu yang sangat lama, karena pelaksanaan pendaftaran tanah bersifat aktif dan teliti

Menurut penulis waktu yang lama karena pendaftaran tanah bersifat aktif dan teliti ini, merupakan "harga" yang harus dibayar, untuk mendapatkan suatu bukti-bukti yang membenarkan pemohon pedaftaran tanah memang pemilik sah dari sebidang tanah yang akan didaftarkan tersebut. kegiatan pendaftaran tanah sebagaimana diatur dalam Peraturan Pemerintah Nomor 24 Tahun 1997,yang berlaku sebenarnya memiliki waktu yang lama dan jika dilihat dari prosedur nya sudah teliti . Pada pasal 11 yang menyatakan kegiatan pendaftaran tanah meliputi kegiatan pendaftaran pertama kali dan pemeliharaan data pendaftaran tanah,dan pada pasal 12 menyatakan kegiatan pendaftaran tanah pertama kali meliputi kegiatan pengumpulan dan pengolahan data fisik, pembuktian hak dan pembukuannya, penerbitan sertifikat, penyajian data fisik dan data yuridis, penyimpanan daftar umum dan dokumen, kegiatan pemeliharaan data pendaftaran tanah.

Pasal 25 Peraturan Pemerintah Nomor 24 Tahun 1997 menyatakan untuk menilai kebenaran alat bukti dilakukan pengumpulan data yuridis mengenai bidang tanah yang bersangkutan oleh panitia ajudikasi dan hasil penelitian tersebut dibuat dalam bentuk daftar isi. Daftar isian tersebut sebagaimana diatur dalam Pasal 26 Peraturan Pemerintah Nomor 24 Tahun 1997 diumumkan selama 30 (tiga puluh) hari untuk pendaftaran tanah secara sistematik dan 60 (enam puluh) hari untuk pendaftaran sporadik, hal ini bertujuan untuk memberikan kesempatan kepada pihak yang berkepentingan untuk mengajukan keberatan.

Dari hal ini dapat dikatakan kegiatan pendaftaran tanah diatas sebenarnya In-

${ }^{67}$ Arisaputra. 
donesia sudah melaksanakan sistem publisitas positif.dengan waktu yang cukup lama, jadi dari segi waktu kekurangan sistem publisitas positif tidak menjadi kendala,

b. Pemilik hak atas tanah yang sebenarnya akan kehilangan hak nya.

Menurut penulis, hal ini dapat terjadi, tetapi jika sistem pendaftaran tanah dilakukan secara teliti, petugas pendaftaran tanah bekerja secara professional, maka resiko pemilik tanah sebenarnya kehilangan hak nya dapat diperkecil. Hal lain yang dapat dilakukan adalah sosialisasi dan edukasi kepada masyarakat tentang sistem publisitas positif tersebut. Sebelum merancang sistem pendaftaran tanah yang baru, masyarakat diharuskan untuk terlabih dahulu memperoleh sosialisasi dari pemerintah. Pada sosialisasi ini masyarakat perlu mengetahui dan memahami dengan baik sistem pendaftaran yang baru, baik keuntungan dan kelebihan sistem maupun ketentuan-ketentuan yang terdapat dalam sistem pendaftaran yang baru ${ }^{68}$

Jika terjadi pemilik asli memang kehilangan haknya maka pemberian kompensasi ganti rugi,dengan menggunakan sistem immediate indefeasible dan deffered indefeasible terhadap pemilik asli yang tanah nya telah diberi hak atas nama orang lain,ini merupakan cara untuk penyelesaian sengketa pertanahan, yang lebih pasti dari segi keadilan

c. Wewenang Pengadilan diletakan dalam wewenang administrasi

Dengan diberlakukan nya kompensasi ganti rugi dalam sistem publisitas positif ,telah jelas wewenang pengadilan untuk menyelesaikan pertanahan bergerser menjadi wewenang administrasi, hal ini menurut penulis pergesaran wewenang penyelesaian sengketa pertanahan menjadi wewenang administrasi lebih memberi rasa keadilan, dan proses penyelesaian tidak berlarut-larut. Kita ketahui proses penyelesaian sengketa di pengadilan mempunyai prosedur yang panjang, menyita banyak waktu dan biaya yang tidak sedikit.bahkan keputusan yang telah mempunyai kekuatan hukum tetap pun ,masih sulit untuk dieksekusi. Beberapa putusan Mahkamah Agung,meskipun tidak dilakukan peninjauan kembali, ternyata ada kesulitan dalam eksekusi dilapangan karena masyarakat menolak putusan tersebut ${ }^{69}$

Penulis,juga mempertimbangkan faktor-faktor lain yang mempengaruhi perubahan sistem publisitas dari sistem publisitas negatif bertendensi positif, menjadi sistem publisitas positif, yaitu sebagai berikut

a. Disiplin dan ketertiban masyarakat Indonesia dalam hal hak-hak atas tanah yang di milikinya untuk didaftarkan.

Sistem publisitas negatif yang bertendensi positif, digunakan pada saat pembentukan peraturan tentang pendaftaran tanah, tidak lepas dari keadaan kondisi masyarakat pada saat itu, dimana akses informasi masih belum begitu berkembang, kondisi sosial ekonomi masyarakat Indonesia pada saat itu juga mempengaruhi. Disiplin dan ketertiban dalam mendaftarkan hak miliknya. Pada era milenial sekarang yaitu tahun

\footnotetext{
${ }^{68}$ Direktorat Tata Ruang dan Pertanahan Kementerian Perencanaan Pembangunan Nasional /Badan Perencanaan Pembangunan Nasional, Kajian Persiapan Perubahan Sistem Pendaftaran Tanah Publikasi Positif Di Indonesia.

${ }^{69}$ Setiawan, Hukum Pertanahan (Pengaturan,Problematika Dan Reformasi Agraria).
} 
2021, keadaan masyarakat, sosial ekonomi d pada saat ini sudah jauh berbeda dan akses informasi sangat berkembang pesat dengan berbagai kemudahan-kemudahan nya. Regulasi tentang pendaftaran tanah juga mengalami perkembangan dengan diterbitkan nya Peraturan Pemerintah Nomor 18 Tahun 2021 Tentang Hak Pengelolaan Hak Atas Tanah,Satuan Rumah Susun dan Pendaftaran Tanah.peraturan ini merupakan aturan pelaksana dari Pasal 142 dan Pasal 185 huruf b Undang Undang Nomor 11 Tahun 2020 Tentang Cipta Kerja. Pada pasal 84 ayat (1) berbunyi Penyelenggaraan dan pelaksanaan Pendaftaran Tanah dapat dilakukan secara elektronik. Digitalisasi kegiatan pendaftaran tanah telah dilaksanakan, menurut penulis hal ini memberikan dampak besar bagi kedisplinan dan ketertiban masyarakat Indonesia dalam hal mendaftarkan hak-hak tanahnya. Kesulitan masyarakat dalam mendaftarkan hak nya oleh teknologi dimudahkan, menurut penulis hal ini menumbuhkan kesadaran masyarakat untuk mendaftarkan tanah nya.

b. Praktek Korupsi Kolusi dan Nepotisme dalam proses pendaftaran tanah

Perjuangan Indonesia pada saat ini memang memberantas segala macam bentuk praktek korupsi,kolusi dan nepotisme. Dalam pendaftaran tanah tidak luput juga dari keitga hal tersebut. hal ini salah satu faktor yang juga harus dipertimbangkan dalam rangka perubahan sistem publistas negatif bertendensi positif .menurut penulis hal yang dapat dilakukan untuk menjauhkan sistem pendaftaran tanah kita dari ketiga hal tersebut adalah beralihnya tata cara permohonan pendaftaran tanah yang semula manual, diganti dengan digitalisasi, dengan perlihan tersebut seluruh dokumen-dokumen pendaftaran tanah disimpan secara elektronik dengan diatur dengan sistem komputerisasi, yang sifatnya terbuka dan jelas. Sehingga praktek korupsi kolusi dan nepotisme dapat dihindari.

c. Keuangan Negara untuk memberikan ganti rugi atas kesalahan memberikan hak atas tanah.

Pemberian kompensasi ganti rugi terhadap kesalahan pemberiah hak atas tanah, memang berhubungan dengan keuangan Negara yang membutuhkan dana besar, ganti rugi dapat terjadi ketika sistem ini diberlakukan, tetapi hal tersebut dapat di tekan resiko nya, yaitu sebelum sistem ini berlaku, maka proses penyelesaian sengketa-sengketa pertanahan yang ada, harus diselesaikan terlebih dahulu.

Bahwa dari uraian diatas yang membahas tentang sistem publisitas positif baik dari segi keuntungan diberlakukan nya sistem tersebut,kekurangan nya juga penulis bahas agar penelitian ini memberikan gambaran secara utuh sistem publisitas positif tersebut, sehingga bisa menjadi bahan pertimbangan .selain itu faktor-faktor diluar dari keuntungan dan kerugian sistem tersebut, juga dibahas faktor lain yang bisa muncul ketika perubahan sistem publisitas positif tersebut diberlakukan.

Dengan demikian sistem pendaftaran tanah yang tepat diberlakukan di Indonesia untuk bisa memberikan perlindungan dan kepastian hukum kepada pemegang sertifikat hak atas tanah, adalah sistem pendaftaran tanah yang menganut sistem publistas positif. Dengan menganut sistem publisitas positif ini, maka kegiatan pendaftaran tanah dan 
pemeliharaan data pendaftaran tanah dapat maksimal, memberikan perlindungan dan kepastian hukum bagi pemegang sertifikat hak atas

\section{PENUTUP}

1. Sistem pendaftaran tanah yang memberikan perlindungan dan kepastian hukum bagi pemegang sertifikat hak atas tanah adalah sistem pendaftaran tanah yang memiliki sistem publikasi positif.

2. Sistem publisitas positif,paling ideal diterapkan dalam sistem pendaftaran tanah di Indonesia yang memberikan perlindungan dan kepastian hukum kepada pemegang sertifikat hak atas tanah. Karena surat tanda bukti hak sebagai alat pembuktian yang kuat, Negara ,menjamin kebenaran data fisik dan data Yuridis yang tercatat dalam surat tanda bukti hak tersebut.

\section{Saran}

1. Untuk mewujudkan sistem pendaftaran tanah dengan sistem publisitas positif, yang memberikan perlindungan dan kepastian hukum bagi pemegang sertifikat hak atas tanah, diperlukan perubahan peraturan di dalam Undang Undang Nomor 5 Tahun 1960 Tentang Ketentuan Dasar Pokok Pokok Agraria, yang berkaitan dengan pendaftaran tanah.

2. Pembentukan peraturan perundang-undangan baru yaitu Undang Undang Pendaftaran Tanah

\section{REFERENSI}

Arisaputra, Muhammad Ilham. Reforma Agraria Di Indonesia. Jakarta: Sinar Grafika, 2015.

Budi, Harsono. "Hukum Agraria Indonesia (Sejarah Pembentukan Undang-Undang Pokok Agraria,Isi Dan Pelaksanaannya).” Universitas Trisakti Jakarta, 2018.

Direktorat Tata Ruang dan Pertanahan Kementerian Perencanaan Pembangunan Nasional / Badan Perencanaan Pembangunan Nasional. Kajian Persiapan Perubahan Sistem Pendaftaran Tanah Publikasi Positif Di Indonesia. Jakarta: Kementerian Perencanaan Pembangunan Nasional/Badan Perencanaan Pembangunan Nasional, 2016.

Marzuki, Peter Mahmud. Penelitian Hukum. Cetakan VI. Jakarta: Prenada Media Group, 2011. Muchtar Wahid. Memaknai Kepastian Hukum Hak Milik Atas Tanah. jakarta: Republika, 2008. Parlindungan, A.P. Pendaftaran Tanah Di Indonesia (Berdasarkan PP No 24 Tahun 1997 Dilengkapi Dengan Peraturan Jabatan Pejabat Pembuat Akta Tanah (PP No 37 Tahun 1998). Bandung: CV. Mandar Maju, 2009.

Sahnan. Hukum Agraria Indonesia. Malang: Setara Press, 2016.

Santoso, Urip. Hukum Agraria Dan Hak-Hak Atas Tanah. Jakarta: Kencana, 2005.

—. Pendaftaran Dan Peralihan Hak Atas Tanah. Jakarta: Prenadamedia Group, 2010.

Setiawan, Ahmad. Hukum Pertanahan (Pengaturan, Problematika Dan Reformasi Agraria). Yogyakarta: LaksBang Justitia, 2019.

Silviana, Ana. "Komparisi Sistem Publikasi Positif \& Negatif Dalam Pendaftaran Tanah Recht Kadaster.” In Power Point Seminar Pertanahan, 15. Semarang, 2020.

Sutedi, Adrian. Tinjauan Hukum Pertanahan. Jakarta: Pradnya Paramita, 2009.

Wardhani, Shinta Novi. "Kekuatan Hukum Sertifikat Hak Atas Tanah Dikaitkan Dengan Kepastian Hukum Dalam Pendaftaran Tanah.” Al-Qanun: Jurnal Pemikiran Dan Pemba- 
haruan Hukum Islam 21, no. 1 (2018): 81-82. https://doi.org/https://doi.org/10.15642/alqanun.2018.21.1.61-84.

Wibawanti, Erna Sri, and R.Mujiyanto. Hak Atas Tanah Dan Peralihannya. Yogyakarta: Liberty, 2013.

\section{Peraturan Perundang-Undangan}

Peraturan Pemerintah Nomor 10 Tahun 1961 tentang Pendaftaran Tanah

Peraturan Pemerintah Nomor 24 Tahun 1997 tentang Pendaftaran Tanah.

Peraturan Pemerintah Nomor 18 Tahun 2021 Tentang Hak Pengelolaan Hak Atas Tanah,Satuan Rumah Susun dan Pendaftaran Tanah

Peraturan Menteri Agraria/Kepala Badan Pertanahan Nasional Nomor 9 tahun 1999 tentang Tata cara Pemberian dan Pembatalan Hak atas Tanah Negara dan Hak Pengelolaan

Undang-Undang Dasar 1945

Undang Undang Nomor 11 Tahun 2011 tentang Anggaran Pendapatan dan Belanja Negara

Undang Nomor 11 Tahun 2020 Tentang Cipta Kerja

Undang Undang Nomor 5 Tahun 1960 Tentang Ketentuan Dasar Pokok Pokok Agraria

Undang-Undang Nomor 5 Tahun 1960 tentang Peraturan Dasar Pokok-pokok Agraria 